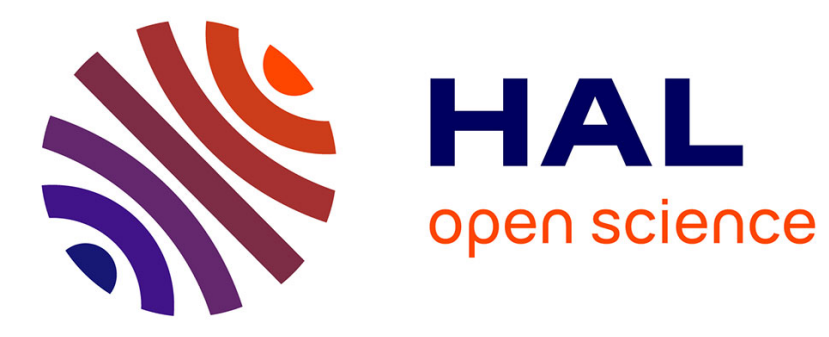

\title{
Design of Rhenium Compounds in Targeted Anticancer Therapeutics
}

Philippe Collery, Didier Desmaele, Vijaykumar Veena

\section{To cite this version:}

Philippe Collery, Didier Desmaele, Vijaykumar Veena. Design of Rhenium Compounds in Targeted Anticancer Therapeutics. Current Pharmaceutical Design, 2019, 25, pp.3306 - 3322. 10.2174/1381612825666190902161400 . hal-03009702

\section{HAL Id: hal-03009702 \\ https://hal.science/hal-03009702}

Submitted on 2 Dec 2020

HAL is a multi-disciplinary open access archive for the deposit and dissemination of scientific research documents, whether they are published or not. The documents may come from teaching and research institutions in France or abroad, or from public or private research centers.
L'archive ouverte pluridisciplinaire HAL, est destinée au dépôt et à la diffusion de documents scientifiques de niveau recherche, publiés ou non, émanant des établissements d'enseignement et de recherche français ou étrangers, des laboratoires publics ou privés. 


\section{REVIEW ARTICLE}

\section{Design of Rhenium Compounds in Targeted Anticancer Therapeutics}

Philippe Collery $^{\mathrm{a}}$ *, Didier Desmaele ${ }^{\mathrm{b}}$, and V. Veena ${ }^{\mathrm{c}^{*}}$

a: Society for the Coordination of Therapeutic Researches, 20220 Algajola, France

b: Institut Galien, Université Paris-Saclay, 92296 Châtenay-Malabry France

c: Biotechnology Department, REVA University, Bangalore, 560064 India

A R T I C L E H I

\section{S T O R Y}

Received:

Revised:

Accepted:

DOI:
Abstract: Many rhenium (Re) complexes with potential anticancer properties have been synthesized in recent years with the aim to overcome the clinical limitations of platinum agents. $\operatorname{Re}(\mathrm{I})$ tricarbonyl complexes are the most common but $\mathrm{Re}$ compounds with higher oxidation states have also been investigated, as well as hetero-metallic complexes and Re-loaded self-assembling devices. Many of these compounds display promising cytotoxic and phototoxic properties against malignant cells but all Re compounds are still at the stage of preclinical studies. In the present review we described the most recent and promising rhenium compounds focusing on their potential mechanism of action including, phototoxicity, DNA binding, mitochondrial effects, oxidative stress regulation or enzyme inhibition. Many ligands have been described, modulating the lipophilicity, the luminescent properties, the cellular uptake, the biodistribution, and the cytotoxicity, the pharmacological and toxicological profile. Re-based anticancer drugs can also be used in targeted therapies by coupling to a variety of biologically relevant targeting molecules. On the other hand, combination with conventional cytotoxic molecules, such as doxorubicin, allowed to take into profit the targeting properties of Re for example toward mitochondria. Through the example of the diseleno-Re complex, we showed that the main target could be the oxidative status, with a down-stream regulation of signaling pathways, and further on selective cell death of cancer cells versus normal cells.

Keywords: Rhenium, Targeted therapy, Cancer, Personalized Treatment, Oxidative Stress Markers,

Signaling

Pathways

\section{INTRODUCTION}

Thousands of significant publications and proceedings of international conferences demonstrating the major roles of metal ions and organometallic compounds in biology and medicine have been published [111]. Many papers have been devoted to the outcome, prevention and, treatment of cancer diseases with trace elements and metal-based drugs. Despite all these efforts, no other metal compounds than platinum (Pt) drugs have been approved for cancer treatments, except in a lesser extent, one arsenic (As) compound 
used to treat an uncommon form of leukemia. Potential therapeutic anticancer metals other than Pt have been investigated, like gallium $(\mathrm{Ga})$, titanium $(\mathrm{Ti})$, ruthenium $(\mathrm{Ru})$, gold $(\mathrm{Au})$, palladium $(\mathrm{Pd})$, copper $(\mathrm{Cu})$ and rhenium $(\mathrm{Re})$, as well as synergistic effects between metal-based drugs and chemotherapeutic agents.

*Equal Correspondence to Philippe Collery, Society for the Coordination of Therapeutic Researches, 20220 Algajola, France Email: philippe.collery@gmail.com and Veena V, Biotechnology Department, REVA University, Bangalore, 560064 India Email: btveenavijaykumar@gmail.com and veena.v@reva.edu.in

While many data were obtained in the domains of synthetic procedures, analytical methods, biophysics and biology, only few clinical trials for $\mathrm{Ru}, \mathrm{Ti}$, or Ga have been published and there is still no nonplatinum metal-based drug approved for the treatment of cancer. Among the many reasons for this failure, it may be advanced that the initial screening based on the determination of the usual concentration inhibiting the growth of $50 \%$ of cancer cells in culture $\left(\mathrm{IC}_{50}\right)$ may not be a good indicator of the clinical efficiency in cancer patients, favoring compound with a poor selectivity on cancer cells versus normal cells. Moreover, in vivo experiments verifying that the therapeutic index is favorable, meaning that the tumor-bearing animals could be cured without any major toxicity are not always performed or the optimal schedule of administration has not been identified. Finally, the lack of success does not mean that metalbased drugs have not been proven effective in the fight against cancer, but just that the development has been stopped at an early stage of biological studies for various reasons including intellectual properties, economic considerations, pharmaceutical companies strategies, etc.

There is a long interest for using Re in medicine for imaging purposes based either on its luminescence properties or on the radioactive beta-emitter isotopes ${ }^{186} \mathrm{Re}$ and ${ }^{188} \mathrm{Re}$ that combine diagnosis by radio- 
imaging with conventional gamma-cameras with therapeutic properties. For example, ${ }^{186} \mathrm{Re}$ radioisotope (90 $\mathrm{h} \mathrm{t}_{1 / 2}, 1.02 \mathrm{MeV} \square-, 137 \mathrm{keV} \square$ ) is used in the treatment of inflammatory joint damage of the shoulder, elbow, wrist, ankle and hip [12,13] whereas, ${ }^{188} \operatorname{Re}(17 \mathrm{~h} \mathrm{t1} / 2,2.11 \mathrm{MeV} \square-, 155 \mathrm{keV} \square)$ is used for therapy of malignant tumors, bone metastases [14], rheumatoid arthritis [15] and other diseases. Finally, it must be emphasized a large number of Re complexes have been developed as cold analogs of the radioactive technetium (Tc) complexes, with the intent to replace isostructural Re by its $99 \mathrm{mTc}$ counterpart for the final application. However, despite that many Re compounds showed high antiproliferative activity and with weak toxicity compared to other heavy metals, "cold" anti-cancer Re compounds have been underestimated as pointed out in the review of Leonidova et al in 2014 [16], furthermore in most cases, their mechanisms of action remain unclear. Among other inorganic compounds, Re merits particular attention, due to its wide range of oxidation states $(-1$ to +7$)$, not only for giving the opportunity to synthesize complexes, with great structural diversity but mainly for its ability to modulate the redox status of cancer cells. By comparison, Pt has only 2 common oxidation states +2 and +4. Only Mn has the same great range of oxidation states than Re, but even though Mn is an essential metal, there is much more risk of toxicity than with Re, particularly for the brain. Thus Re has many advantages over platinum, it is cheaper, has a wider range of mechanisms of action and most rhenium(I) tricarbonyl derivatives possess diverse photophysical and photochemical properties allowing theragnostic approaches.

Herein we review the most relevant and recent Re complexes, covering their biophysical properties, their biological effects, their pharmacological and toxicological profiles and their antitumor properties. We will highlight a Re diselenoether complex as it is at a more advanced stage, with defined targets on cancer cells. This selected compound appears a suitable candidate for the development of personalized and targeted anticancer therapy, guided by markers, in a specific indication of a very aggressive human breast cancer. 


\section{1. CHEMICAL STRUCTURES}

Re is a metal with atomic number 75 of the third row of transition metals, below Mn and Tc. Re is one of the rarest elements in the earth crust with an estimated average concentration of 1 part per billion and it is not present in humans. Re is mainly used for aerospace industries. It is one of the top ten most expensive metals, but it remains cheaper than platinum that is widely used for cancer treatments. Its electronic configuration is $[\mathrm{Xe}] 4 \mathrm{f}^{14} 5 \mathrm{~d}^{5} 6 \mathrm{~s}^{2}$. Its peculiar valence electrons arrangement permits a large variety of oxidation state supporting a diverse set of ligand types and coordination geometries. The fine-tuning of the ligands on the metal environment will modulate their lipophilicity, the luminescent properties, the cellular uptake, the biodistribution, the cytotoxicity, their pharmacological and toxicological profile. The mode of administration may also have an important impact on the anticancer activity.

$\operatorname{Re}(\mathrm{I})$ complexes constitute the most preeminent group of anticancer $\operatorname{Re}$ compounds and the $\operatorname{Re}(\mathrm{I})$ tricarbonyl subunits $\left[\operatorname{Re}(\mathrm{I})(\mathrm{CO})_{3}\right]$ is the most commonly synthetized Re organometallic fragment among them. A myriad of mono- and bisdentate heteroatomic ligands have been coupled to this stable scaffold. To date, all the $\operatorname{Re}(\mathrm{CO})_{3}$ complexes studied for their potential anticancer activity display the $f a c-\operatorname{Re}(\mathrm{CO})_{3}$ configuration, which is clearly favorably obtained by simple ligand exchange from $\operatorname{Re}(\mathrm{CO})_{5} \mathrm{Cl}$. It is worthy of note that no effort has been made to separate the pair of metal-centered enantiomers formed when dissymmetrical ligands were used. Although most described complexes relied on mono- or bidentate nitrogen ligands, combination with oxygen, sulfur $(\mathrm{S})$ and even selenium (Se) donor atoms have been proposed [17,18]. For example, a $\operatorname{Re}(\mathrm{I})(\mathrm{CO})_{3}$ complex of 21,23-diselenaporphyrin in which the $(\mathrm{CO})_{3} \operatorname{Re}(\mathrm{I})$ moiety was bound to both the Se atoms and one of the $\mathrm{N}$ atoms of the porphyrin core was described [19], likewise a $(\mathrm{CO})_{3} \operatorname{Re}(\mathrm{I})\left(\mathrm{Se}^{\wedge} \mathrm{Se}\right)$ diselenoether complex [20,21] appeared as a promising drug candidate. In an attempt to overcome difficulties to identify the best ligand a combinatorial approach was recently adopted and permit to discover the new Re complex 1 (Fig. 1) highly active in wild-type and cisplatin-resistant A2780 ovarian cancer cells indicating that modulation of conventional bidentate 
heterocyclic ligands can still bring novelty in a well explored chemical space [22]. The $\eta^{5}$ cyclopentadienyl group has emerged as an alternative versatile organometallic fragment to build Reanticancer agents. For example, complex 2b was found highly active on pancreatic adenocarcinoma PT-45 cell line reaching an IC50 value of $11.5 \mu \mathrm{M}$ while $2 \mathbf{a}$ is devoid of activity [23]. Beside $\operatorname{Re}(\mathrm{I})(\mathrm{CO})_{3}$ compounds, new derivatives emerged based on the $N$-heterocyclic carbene complexes scaffold such as 3 . $\operatorname{Re}(\mathrm{I})-\mathrm{NHC}$ complexes were found clearly superior to most Ru carbenes and carboplatin against a large panel of cancer cell lines with IC50 values below $10 \mathrm{mM}$, but most importantly, and it was established that the $\mathrm{Re}(\mathrm{I})-\mathrm{NHC}$ tricarbonyl fragment is responsible for the high activity. The properties and prospects for $\operatorname{Re}(\mathrm{I})$ tricarbonyl $N$-heterocyclic carbene complexes have been recently reviewed [24].

Higher oxidation states of $\operatorname{Re}$ have been much less investigated. The $\operatorname{Re}(\mathrm{II})$ complex $\left[\mathrm{Re}(\mathrm{NO})(\mathrm{CN})_{4}\left(\mathrm{H}_{2} \mathrm{O}\right)\right]^{-} \mathrm{PhenH}^{+}$. $\left(3 \mathrm{H}_{2} \mathrm{O}\right)(\mathrm{Phen})$ was reported to interact with calf thymus DNA through partial intercalation into DNA bases but its cytotoxicity was not reported [25]. Re $\mathrm{III}$ complexes $\left(\mathrm{d}^{4}\right)$ are anticipated to be more inert to ligand exchange than $\mathrm{d}^{2} \mathrm{Re}^{\mathrm{V}}$ complexes [26]. The Dirhenate(III) complex 4 with an unusual quadruple $\mathrm{Re}-\mathrm{Re}$ bond was shown to have significant efficacy in sarcoma-, leukemia-, and melanoma-bearing mice models. However it was later found that such compounds decomposed readily into insoluble Re oxides, requiring high doses to get a significant therapeutic effect [27].

$\operatorname{Re}(\mathrm{IV})$ is a $5 \mathrm{~d}^{3}$ ion that usually forms octahedral complexes displaying structural similarity to those of $\mathrm{Pt}(\mathrm{IV})$. Nevertheless only few Re (IV) complexes have been studied. $\mathrm{ReCl}_{4}\left(\mathrm{~N}^{\wedge} \mathrm{N}\right)$ where $\mathrm{N}^{\wedge} \mathrm{N}$ is a $2,2^{\prime}$ dipyridine or 1,10-phenanthroline ligand showed micromolar antiproliferative activity against MCF-7 breast, BG1 ovarian and LnCaP prostate cancer cells [28].

Simple cationic bis(cyclopentadienyl)Re(V) complexes were evaluated in the Ehrlich ascites tumor system and induced a maximal cure rate of $100 \%$ when given either in a dose range of $120-160 \mathrm{mg} / \mathrm{kg}$ (rhenocene trichloride 5a) or at a single dose of $180 \mathrm{mg} / \mathrm{kg}$ (hexafluoroarsenate derivative 5b) [29]. Lippard reported that $\operatorname{Re}(\mathrm{V})$ oxo complexes of general formula $\left[\mathrm{Cl}_{2} \operatorname{ReO}(\mathrm{OMe})\left(\mathrm{N}^{\wedge} \mathrm{N}\right)\right]$, where $\mathrm{N}^{\wedge} \mathrm{N}=$ 
substituted phenanthroline, selectively kill cancer cells over normal cells and display markedly higher cell toxicity than cisplatin [30]. Chelation of the $\operatorname{Re}(\mathrm{V})$ oxo ion with two pyridylthiocarbazide ligands gave a square pyramidal complex with the oxo group in the apical site [31]. Enlarging this finding to the corresponding nicotinylthiosemicarbazide ligand offered an additional free carboxylic group available to append targeting molecule. Such a strategy has been used to tether the $\operatorname{Re}(\mathrm{V})$ to Tyr3-octreotate and cyclic-RGD tumor targeting peptides [32]. Many heterobimetallic compounds have been synthesized including $\operatorname{Re}(\mathrm{IV}) / \mathrm{Mo}(\mathrm{VI}), \mathrm{Zn}(\mathrm{II}) / \mathrm{Re}(\mathrm{IV})$ or $\mathrm{Re}(\mathrm{I}) / \mathrm{Tc}(\mathrm{I})$ combinations [33-35]. Among them the $\mathrm{Re}-\mathrm{Fe}$ [36], Re-Au (7, Fig. 1)[37] and Re-Pt [38] heterobimetallic complexes showed a good cytotoxic activity combined with a strong fluorescence associated with a metal-to-ligand charge transfer making same useful theragnostic candidates. HepG2 tumoral cells were found more sensitive than HUVEC cells to the inorganic cluster $\left[\operatorname{Re}_{6} \mathrm{Se}_{8} \mathrm{I}_{6}\right]^{3-}\left[n-\mathrm{Bu}_{4} \mathrm{~N}^{+}\right]_{3}$ which was found to accumulate in nucleus where it induced apoptosis [39].

Following the early findings of Shtemenko et al. that liposomal formulation of dinuclear cluster Re compounds had better therapeutic effects than their solutions [40], an increasing number of Re-containing nanodevices were explored in the past few years. For example, self-assembling of the copolymer 8 (Fig. 1) made byRAFT copolymerization of diacetone acrylamide and PEG-acrylate followed by grafting the bisquinoline $(\mathrm{CO})_{3} \operatorname{Re}$ complex through imine bond formation gave star polymer nanoparticles. When low cytotoxicity on Hela cell line was observed in the dark $(41 \mu \mathrm{M})$, a fourfold increased in potency occurred upon 10 min irradiation with $350 \mathrm{~nm}$ UV light [41]. 


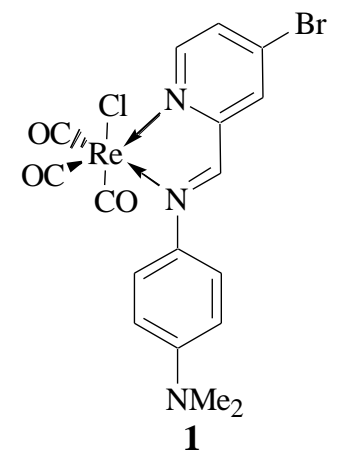

1

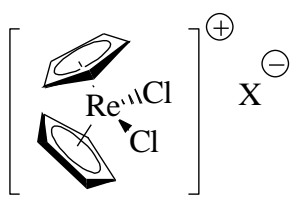

5a, $\mathrm{X}=\mathrm{Cl}$,

5b, $\mathrm{X}=\mathrm{AsF}_{6}$

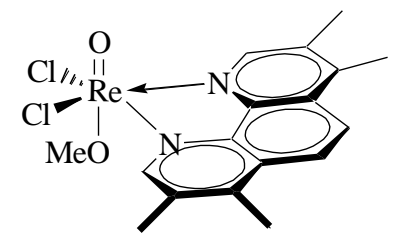

6

$\mathbf{2 a}, \mathrm{X}=\mathrm{CO}$

2b, $\mathrm{X}=\mathrm{PPh}_{3}$<smiles>O=C(Cl)[Ge]1(Br)N2C=CC=CN2c2nccn21</smiles>

3

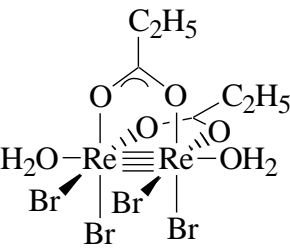

4

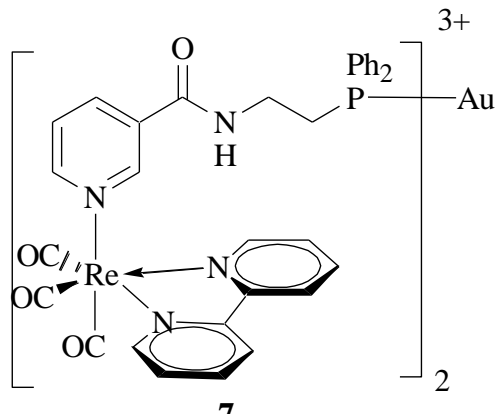

7

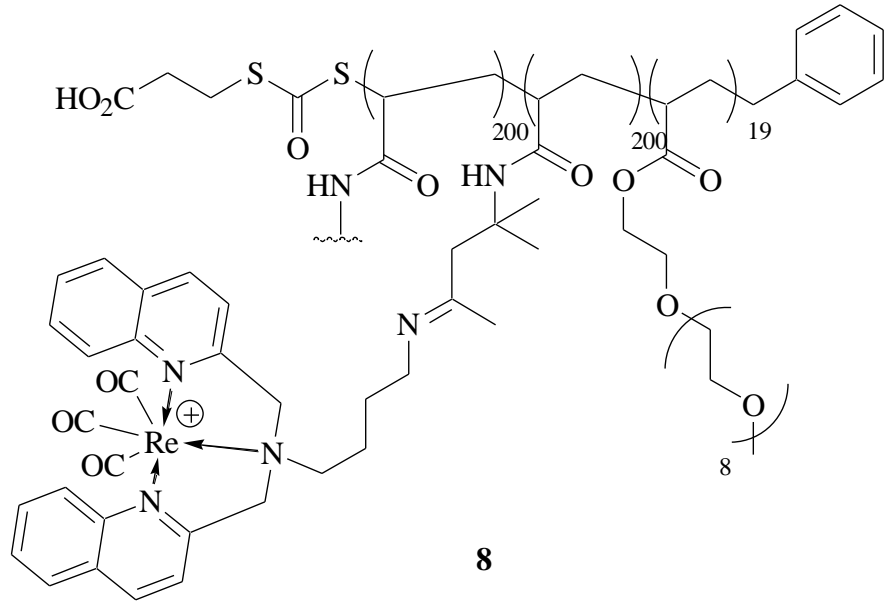

Fig. (1). Summary of some typical classes of rhenium organometallic compounds with anticancer properties.

\section{BIOPHYSICAL PROPERTIES OF RHENIUM-BASED COMPOUNDS}

\subsection{Luminescent properties of Re compounds}

Besides their potential cytotoxic activity, one of the main impetuses for the development of Re compounds is their luminescence properties that could be used by fluorescence microscopy for cell imaging. In particular, when substituted with appropriate aromatic or heteroaromatic ligands, the $(\mathrm{CO})_{3} \mathrm{Re}$ fragment displays intense emission with large Stokes shifts upon irradiation. The main origin of the 
phenomenon is a metal-to-ligand charge transfer (MLCT) leading to a long-lived triplet state. A strong MLCT absorption in the visible region with long wavelength is essential to get photophysical properties for transition metals-based compounds. On the other hand, the introduction of electron-withdrawing groups into the electron-accepting ligand and/or weak-field ligands into the central metal shortened excited-state lifetime lowered the emission efficiency and lowered oxidation and reduction power [42].

The luminescent properties of many $\operatorname{Re}(\mathrm{CO})_{3}$ polypyridine complexes, displaying triplet charge transfer emission, have been recently review by Lo. et al. According to them, the main advantages of Re complexes over other luminescent devices is their high photostability, long-lived phosphorescence allowing time-resolved detection and large Stokes shifts minimizing the self-quenching effects $[43,44]$. Octahedral $\mathrm{d}_{6}$ low-spin $\operatorname{Re}(\mathrm{CO})_{3}$ complexes have luminescent properties, but the luminescence quantum yield increased for complexes bearing long alkyl chains resulting in an improvement of their detection in MDA-MB231 breast cancer cells [45]). However the use of these complexes as luminescent labels and probes for biomolecules was thwarted by their low solubility, thus PEG-conjugation has been devised by grafting polyethylene chains on the phenanthroline ligand. Laser-scanning confocal microscopy showed that such pegylated Re complexes accumulate in mitochondria when incubated in HeLa cells [46]. Among the factors affecting the luminescence efficiency, the geometrical arrangement around the metal and more precisely the choice of the axial ligand is fundamental to control the relevant features. The comparison of a series of Re tricarbonyl complexes based on tridentate phenanthridine-containing ligands shown that the complex possessing a quinoline axial ligand demonstrated the most beneficial staining and luminescence properties with shortest exposure times and brightest than the complexes with pyridine or phenanthridine ligand [47]. While $(\mathrm{CO})_{3} \operatorname{Re}(\mathrm{I})$ showed both luminescent and anticancer properties, multivalent dinuclear complexes featuring two $\operatorname{Re}(\mathrm{CO})_{3}$ units connected by a substituted diazine ligand and two anionic ancillary ligands glycodendron bearing three glucose units displayed interesting bio-imaging properties, 
with a high cell permeability and organelle selectivity. These glyco-Re derivatives that benefit of a low cytotoxicity and fast internalization could represent interesting phosphorescent probes suitable for cell imaging application, but not as anticancer drugs [48]. Water soluble hexarhenium cluster complexes with a benzotriazolate apical ligand exhibited luminescence with high lifetimes and quantum yield values. They were easily taken up by the cells illuminating them under UV irradiation but did not show acute cytotoxic effects constituting a new class of phosphorescent dyes a [49].

Beside the $\operatorname{Re}(\mathrm{I})(\mathrm{CO})_{3}$ complexes, a small number of luminescent $\operatorname{Re}(\mathrm{II})$ complexes generally coordinated to $\eta^{5}$-Cp ligands have also been reported [50]. Likewise, the luminescent properties of cytotoxic heterobimetallic and -trimetallic complexes of $\mathrm{Re}-\mathrm{Au}$ have been attributed to a triplet MLCT transition $(\operatorname{Re}(\mathrm{d} \pi)$ $\left.\rightarrow \operatorname{bipy}\left(\pi^{*}\right)\right)$. Their uptake in A549 lung cancer cells was followed by fluorescence microscopy showing a non-uniform cytoplasmatic distribution with a clear accumulation at the edge of the inner cell membrane as well as in areas within the nucleus [37] .

\subsection{Photodynamic Therapy with Re complexes}

The cytotoxicity of the Re complexes and their bioconjugates increased significantly upon light irradiation. Thus, $\operatorname{Re}$ complexes and particularly $(\mathrm{CO})_{3} \operatorname{Re}(\mathrm{I})$ derivatives have been synthesized as photosensitizer agents for photodynamic therapy (PDT). They proved to be excellent singlet oxygen $\left({ }^{1} \mathrm{O}_{2}\right)$ generators in a lipophilic environment with high quantum yields. The use of $(\mathrm{CO})_{3} \operatorname{Re}(\mathrm{I})$ as probes and drugs in PDT has been thoroughly reviewed up to 2016 [51]. To improve the selectivity towards cancer cells the Re photosensitizers have been coupled to a variety of biologically relevant targeting molecules including cell permeation peptides, biotin, folic acid etc. For example, the coupling of the rhenium moiety 9 (Fig. 2) with either a nuclear localization signal peptide (NLS) or the neuropeptide bombesin known to target an overexpressed receptor at the surface of cancer cells formed Re bioconjugates Re-NLS and Rebombesin, respectively. Fluorescent microscopy on cervical cancer cells (HeLa) showed that the conjugation of 9 to NLS significantly enhanced the accumulation of Re into the cell nucleus. Re-bombesin 
was found to be at least 20 -fold more toxic after light irradiation. DNA photo-cleavage studies demonstrated that the compound damaged DNA via ${ }^{1} \mathrm{O}_{2}$ and to a minor extent, superoxide production [52].

The Meggers's team showed that pyridocarbazole Re complexes with a pyridine ancillary ligand 11a (Fig. 2) were able to induce apoptosis upon irradiation $(\lambda \geq 505 \mathrm{~nm})$ through efficient generation of ${ }^{1} \mathrm{O}_{2}$, but were inactive in the dark [53]. They further compared different complexes bearing an ancillary imidazole ligand 11b (Fig. 2) and were further modified with $\pi$-donating or $\sigma$-accepting groups. They demonstrated that $\pi$-donating groups on the indole moiety completely suppressed the formation of ${ }^{1} \mathrm{O}_{2}$, whereas $\sigma$ accepting fluorine and trifluoromethyl derivatives efficiently produced ${ }^{1} \mathrm{O}_{2}$ when irradiated with visible light. The complex harboring a fluorine in the 3-position of the pyridine moiety displayed the most pronounced light-induced antiproliferative effect in HeLa cancer cells when irradiated at $\lambda \geq 580 \mathrm{~nm}$ [54]. $\operatorname{Re}(\mathrm{CO})_{3}$ complexes bearings water-soluble tris(hydroxymethyl)phosphine (THP) ligand or 1,3,7-triaza-5phosphabicylco[3.3.1]nonane (DAPTA) ligand (10, Fig. 2) exhibited triplet-based luminescence in airequilibrated aqueous solution. The THP and DAPTA complexes undergo photosubstitution of a CO ligand upon irradiation with $365 \mathrm{~nm}$ light with quantum yields ranging from 1.1 to $5.5 \%$ and sensitized the formation of ${ }^{1} \mathrm{O}_{2}$, with quantum yields as high as 70 . These complexes exhibited a cytotoxic response on human cervical (HeLa), ovarian (A2780), and cisplatin-resistant ovarian (A2780CP70) cancer cell lines upon irradiation but were devoided of toxic effect in the absence of light. The phototoxic response has been attributed to the intrinsic effect of Re metal but also to the release of $\mathrm{CO}$ as well as the production of ${ }^{1} \mathrm{O}_{2}[55]$

A flake-like ultrathin Re disulfide nanosheets covered of BSA and functionalized with folic acid-tethered PEG-chains was loaded with resveratrol (utReS2@RSV). Near infrared (NIR) 808 nm laser irradiation induced resveratrol release in tumor cells. NIR irradiation 5 min once a day of the tumor after 
utReS2@RSV injection in HepG2 tumor-bearing nude mice, completely suppressed the tumor after 30 days [56].

Luminescent heterobimetallic $\operatorname{Re}(\mathrm{I}) / \mathrm{Au}(\mathrm{I})$ complexes in which the $\mathrm{Au}$ moiety is bound on the apical pyridine ancillary ligand through an alkyne spacer exemplified by complex 12 (Fig. 2) were recently studied. The emissive properties are dominated by the NHC-Re(I) fragment. A weak antiproliferative effect $(11 \mu \mathrm{M})$ was observed after incubation in A549 cells in the dark, however, upon irradiation at 405 $\mathrm{nm}$, the $\mathrm{IC}_{50}$ reached $2.6 \mu \mathrm{M}$ while the corresponding monometallic Re complex did not show any increase of the antiproliferative activity when irradiated [57]. A similar combination of $\mathrm{Re}$ and $\mathrm{Pt}$ heterobimetallic complex exhibited moderate dark cytotoxicity against HeLa or cisplatin-resistant human ovarian epithelial A2780 cancer cell lines, and a selective activity upon light irradiation [58]. Finally, octahedral Re/Se cluster complexes $\left[\left\{\mathrm{Re}_{6} \mathrm{Se}_{8}\right\}(\mathrm{CN})_{6}\right]^{4-}, 4 \mathrm{Na}^{+}$showed low cytotoxicity in the dark and photodynamic cytotoxicity on human larynx carcinoma Hep-2 cells while the corresponding sulfur derivatives were much less active [59]. A very unusual series of aryldipyrrinato $\operatorname{Re}(\mathrm{CO})_{3}$ complexes have been recently proposed as potential photosensitizers able to generate singlet oxygen under visible light irradiation [60]. 


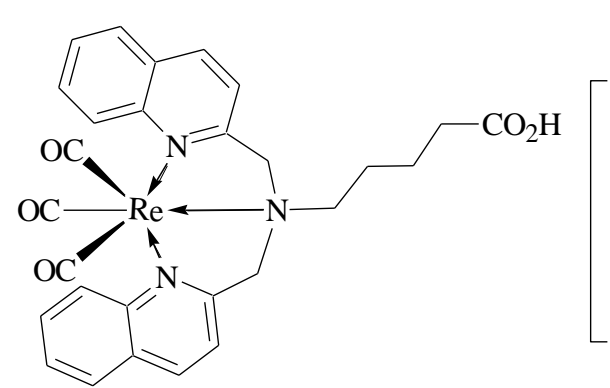

9

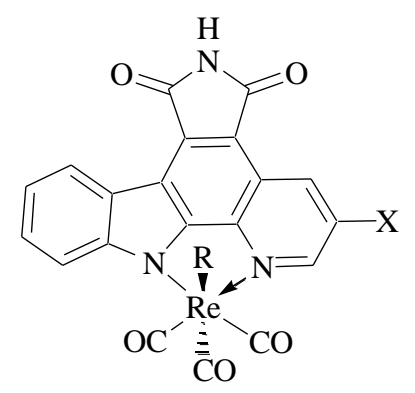

11a: $\mathrm{R}=$ pyridine

11b: $\mathrm{R}=$ imidazol $\mathrm{X}=\mathrm{H}, \mathrm{F}, \mathrm{CF}_{3}$
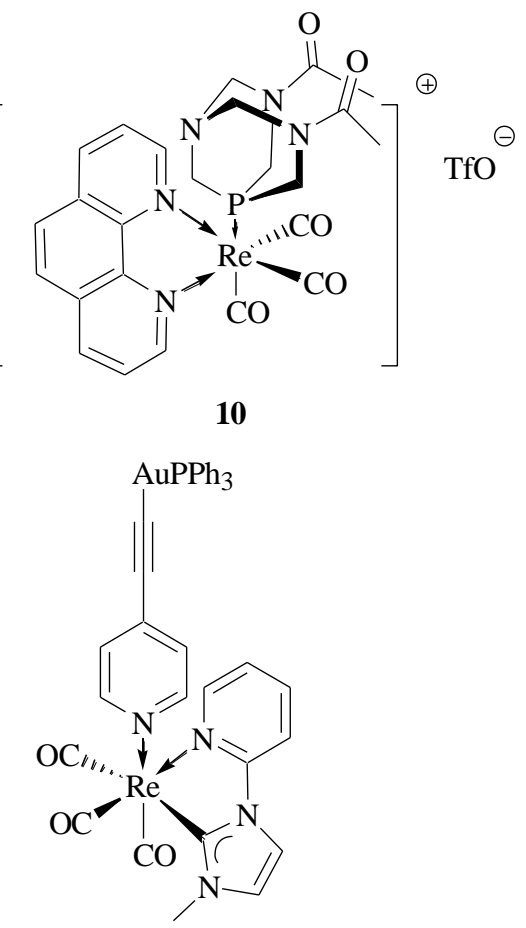

12

Fig. (2). Structures of the typical classes of luminescent rhenium complexes with potential Photodynamic Therapy applications

\subsection{Carbon monoxyde release from $(\mathrm{CO})_{3} \operatorname{Re}$ complexes}

Small doses of CO selectively induce cancer cell death via apoptosis. Thus, metal carbonyl compounds have been used as cargo to deliver $\mathrm{CO}$ in cells (CO-releasing molecules, CORM). Most transition-metal carbonyl compounds have in common the possibility to release carbon oxide (CO) according to a large variety of mechanisms involving light, enzyme or chemicals. It may be difficult to distinguish between metal and $\mathrm{CO}$ contributions in the overall cytotoxicity of the $\operatorname{Re}(\mathrm{CO})_{3}$ fragment. In this respect, the development of manganese-based photo-CORMs might highlight the specific role of both entities [61]. Early attempts to use $\operatorname{Re}$ complexes to deliver $\mathrm{CO}$ to cells involved $\operatorname{Re}(\mathrm{II})$ complexes such as $\left[\operatorname{ReII}(\mathrm{CO})_{2} \mathrm{Br}_{2} \mathrm{~L}_{2}\right]$ that spontaneously released $\mathrm{CO}$ in physiological medium [62]. However, it turned out to be much more advantageous to trigger the release of $\mathrm{CO}$ using external irradiation. The main challenge when looking for Re based photo-CORM is to design daylight-stable complexes able to slowly release the $\mathrm{CO}$ upon UV-light photolysis in order to avoid rapid reaching of cytotoxic levels of carbon monoxide 
(CO). Simple bipyridine (bpy) ligand fulfilled this goal. While, (bpy) $\operatorname{Re}(\mathrm{CO})_{3} \mathrm{Cl}$ is photoinerte, the corresponding cationic complex stabilized by a water soluble phosphine $\left[(\text { bpy }) \operatorname{Re}(\mathrm{CO})_{3} \mathrm{P}\left(\mathrm{CH}_{2} \mathrm{OH}\right)_{3}\right]^{+}$ possessed a photolabile axial CO. When irradiated at $405 \mathrm{~nm}$ the fluorescence of the dissociated complex can be detected inside PPC-1 prostate carcinoma cells using confocal fluorescence microscopy [63]. Many other cationic $\operatorname{Re}(\mathrm{CO})_{3}$ photo-CORM complexes were proposed such as $\left[(\text { pyridyl)benzothiazol })(\mathrm{PTA}) \operatorname{Re}(\mathrm{CO})_{3}\right]^{+}$in which the $1,3,5$-triaza-7-phosphaadamentane (PTA) is the ancillary ligand [64] or $\left[\left(\operatorname{phen}\left(\mathrm{PPh}_{3}\right) \operatorname{Re}(\mathrm{CO})_{3}\right]^{+}[65]\right.$. Both complexes were found to easily penetrate inside MDA-MB-231 human breast cancer cells. In another study in human MDA-MB231 breast cancer cells, the rapid release of $\mathrm{CO}$ from the cationic complex $[($ pyridyl $)$ benzothiazol $\left.) \operatorname{Re}(\mathrm{CO})_{3}\left(\mathrm{H}_{2} \mathrm{O}\right)\right]\left(\mathrm{CF}_{3} \mathrm{SO}_{3}\right)$ upon exposure to $302 \mathrm{~nm}$ light was followed by reduction of its original orange luminescence to a deepblue fluorescence signal, the release of $\mathrm{CO}$ being responsible of the phototoxic effects on the malignant cells [66].

The comparison between two 2-phenylazopyridine (azpy) $\operatorname{Re}$ compounds $\left[(\operatorname{azpy}) \operatorname{Re}(\mathrm{CO})_{3} \mathrm{Br}\right]$ and $\left[(\right.$ azpy $\left.) \operatorname{Re}(\mathrm{CO})_{3}\left(\mathrm{PPh}_{3}\right)\right] \mathrm{ClO}_{4}$ has been performed. The $\left[(\right.$ azpy $\left.) \operatorname{Re}(\mathrm{CO})_{3} \mathrm{Br}\right]$ complex exhibited strong MLCT bands in the 500-600 $\mathrm{nm}$ region and strong spin-orbit coupling (prominent in heavy metals) that promoted intersystem crossing to a triplet state, considered to prevent $\mathrm{CO}$ release upon illumination with visible light. Slow release of $\mathrm{CO}$ from $\left[(\operatorname{azpy}) \operatorname{Re}(\mathrm{CO})_{3}\left(\mathrm{PPh}_{3}\right)\right] \mathrm{ClO}_{4}$ indicated that strong $\sigma$-donating ligands, such as $\mathrm{Br}^{-}$, accelerated the rate of $\mathrm{CO}$ photorelease relative to $\pi$-acid ligands [67].

Interestingly, a non-cationic sulfonated water soluble $\mathrm{Re}[$ bis(arylimino)acenaphthene $](\mathrm{CO})_{3} \mathrm{Cl}$ complex fused to an acenaphthylene was found to permanently release $\mathrm{CO}$ with a rate of $40-50 \mathrm{nmol} \mathrm{CO} / \mathrm{h} / \mathrm{mg}$ when activated by light in aqueous solution [68].

Many $\operatorname{Re}(\mathrm{CO})_{3}$ complexes possess a dual mechanism involving ${ }^{1} \mathrm{O}_{2}$ and $\mathrm{CO}$ release. It is the case of previously mentioned $\operatorname{Re}(\mathrm{CO}) 3$ complexes bearing water-soluble tris(hydroxymethyl)phosphine. Their 
phototoxic response was attributed to the release of both $\mathrm{CO}$ and the Re-containing photoproduct, as well as the production of ${ }^{1} \mathrm{O}_{2}[55]$.

A photo-active luminescent phenanthrenyl $\operatorname{Re}(\mathrm{I})(\mathrm{CO})_{3}$ complex grafted on a biocompatible carboxymethyl chitosan matrix through an apical pyridine ligand was able to eradicate human colorectal adenocarcinoma cells (HT-29) very efficiently in a dose-dependent fashion by low power UV light-induced CO delivery. Caspase-3/7 activation by $\mathrm{CO}$ delivery was evidenced with the aid of confocal microscopy [69] .

\section{BIOLOGICAL EFFECTS}

\subsection{DNA effects of Re complexes}

The binding of $\operatorname{Re}(\mathrm{I})$ compounds with DNA bases, with the formation of single or double strand adducts is well documented. Re can bind to adenine through the N1, N6 positions or to guanine through the N7 position. Both, Re/nucleotide 1:1 or Re/ nucleotide 1:2 adducts have been observed. The binding of $\operatorname{Re}\left(\mathrm{CO}_{3}\right)$ compounds with Me-guanine used as model compound could result in either head-to-head $(\mathrm{HH})$ or head-to-tail (HT) conformers of cis-bis guanine ligands [70-74]. The peculiar mode of binding of Re may play an important role in their anticancer activity because unlike cisplatin which forms irreversible square-planar Pt adducts, binding of Re drugs to one or two bases is reversible, with the formation of less stable octahedral-Re adducts [70]. Spectral, viscosity and molecular docking studies are typically used to establish the formation of a groove binding adduct between $\operatorname{Re}(\mathrm{I})$ complexes and calf thymus DNA [75]. For example, (pentylcarbanato)Re(I) diimine complexes have been shown to bind DNA through intercalation and provided strong cytotoxic effects on lymphosarcoma, PC-3 prostate and myeloid leukemia. They were more potent than cisplatin on these cancer cells, but in contrast exhibited less toxicity in the normal glomerular mesangial cells. They were also effective on MDA-MB-468 (HTB-132) cell lines, corresponding to a model of triple negative breast cancer [76].

The recently described series of (polypyridyl) $\operatorname{Re}(\mathrm{CO})_{3}$ complexes bearing axial acetylsalicylato ligand were shown by DFT calculations to display a planar configuration. The UV titration of these complexes 
showed that their absorbance decreased with addition of DNA without any red shift suggesting that these complexes did not follow intercalation mechanism but were more likely to bind to the minor grooves of the DNA double helix [77]. On the other hand, the structurally similar $\operatorname{Re}\left(\mathrm{CO}_{3}\right)$ pentylcarbonato complexes in which each Re atom was tethered to a nearly planar polypyridyl aromatic ligand, were found to bind through an intercalation mechanism as evidenced by X-ray structure determinations and DFT calculations [78].

$\operatorname{Re}(\mathrm{CO})_{3}$ complexes can bind covalently to guanine nucleobases via substitution of their labile ligand but $\operatorname{Re}(\mathrm{CO})_{3}$ complexes that do not contain labile ligand, can also interact with DNA, non-covalently, either through intercalation or groove binding. On the other hand, when the labile ligand bore a long alkyl chain, their lipophilic appendages played a key role in DNA binding to fit with the minor groove [79]. Likewise, the structure-activity relationships of (diimines) $\operatorname{Re}(\mathrm{CO})_{3}$ complexes with different sulfonato and carboxylato group as axial ancillary ligand in hormone-dependent MCF-7 and hormone-independent triple negative MDA-MB231 breast cancer cells suggested that the cytotoxic effects increased with their lipoliphilicy and that could be related with their DNA-binding ability [80].

The DNA binding modelling studies of $\left[\operatorname{Re}(\mathrm{CO})_{3}(2\right.$-appt $\left.) \mathrm{Cl}\right]$ complexes where 2-appt $=2$-amino-4phenylamino-6-(2-pyridyl)-1,3,5-triazine has revealed that the complexes were able to bind in the minor groove of double stranded DNA helix. The model was experimentally validated by calf thymus DNA binding study using UV-Vis spectroscopy. Furthermore, the complexes were efficient in the DNA cleavage activity [81]. The binding of Re to DNA is not limited to $(\mathrm{CO})_{3} \operatorname{Re}(\mathrm{I})$ complexes, most Re-based complexes interact with DNA, which is a common target for metal-based drugs. Thus, $\operatorname{Re}(\mathrm{II}), \operatorname{Re}(\mathrm{III})$ and $\operatorname{Re}(\mathrm{V})$ were also found to give DNA adducts. Re(II) dinitrosyl and mononitrosyl complexes interacted with calf thymus DNA through partial intercalation of DNA bases and were capable of inducing cleavage of plasmid DNA in the presence of $\mathrm{H}_{2} \mathrm{O}_{2}$ [25]. $\mathrm{Re}(\mathrm{III})$ complexes, as tetrapropionato-diRe (III) [82], or cis-tetrachloro-dipivalato-diRe(III) complexes [83], which contain Re-Re quadruple bonds interacted with 
DNA, forming covalent interstrand cross-links and inducing DNA cleavage. In the case $\left[\operatorname{Re}_{2}(i-\right.$ $\left.\left.\mathrm{C}_{3} \mathrm{H}_{7} \mathrm{COO}\right)_{4} \mathrm{Cl}_{2}\right]$ di-Re(III) complexes, a binding of two 9-methylguanine and 9-methyladenine bases per dirhenium unit in a bidentate fashion was observed, via N7/O6 and N1/N6 sites respectively, with concomitant substitution of two carboxylate groups [84]. The DNA interaction capabilities of two thiophene-2-carbohydrazide $\operatorname{Re}(\mathrm{V})$ complexes were gauged via UV/Vis spectroscopy and gel electrophoresis studies. A good correlation was observed between the DNA cleavage efficiency and the redox potentials of the metal complexes [85].

\subsection{Interactions of Re-complexes with proteins.}

The binding of Re compounds to DNA may play a role in their cytotoxicity against malignant cells, but other biological consequences have to be determined. Proteins are clearly the second target of $\operatorname{Re}(\mathrm{I})$ complexes and $\mathrm{Re}$ covalent modifications on the histidine, glutamate, aspartate, and C-terminal carboxylate groups of peptides have been reported [86]. For example, binding between $\operatorname{Re}(\mathrm{CO})_{3}\left(\mathrm{H}_{2} \mathrm{O}\right)_{3}{ }^{+}$ cation and the histidine of lysozyme was observed with the formation of a single covalent adduct [87].

Metallothioneins constitute a family of low molecular weight proteins with the ability to bind metals of physiologically interest such as Zinc $(\mathrm{Zn})$ or Copper $(\mathrm{Cu})$. The incorporation of a $\operatorname{Re}(\mathrm{CO})_{3}$ core into the Zn-metallothioneins $(\mathrm{Zn}-\mathrm{MT})$ has been observed with the $\left[\operatorname{Re}\left(\mathrm{H}_{2} \mathrm{O}\right)_{3}(\mathrm{CO})_{3}\right]+$ cation through a transmetallation reaction between $\mathrm{Zn}$ and $\mathrm{Re}$ leading to the formation of mixed-metal species as fac$\left[\mathrm{Zn}_{6}\left[\operatorname{Re}(\mathrm{CO})_{3}\right]-\mathrm{MT}\right.$, fac- $\left[\mathrm{Zn}_{6}\left[\operatorname{Re}(\mathrm{CO})_{3}\right]_{2}-\mathrm{MT}\right.$ and fac- $\left[\mathrm{Zn}_{5}[\operatorname{Re}(\mathrm{CO})]_{3}-\mathrm{MT}\right.$ [88]. The replacement of $\mathrm{Zn}(\mathrm{II})$ by $\operatorname{Re}(\mathrm{I})$ when binding to S-donor ligands appeared triggered by the higher stability of a metal complex of the third transition row with a d6 configuration versus that of the first transition series with a d10 configuration [89].

The binding interaction of $\operatorname{Re}(\mathrm{I})$ polypyridine complexes with bovine serum albumin (BSA) showed that their ${ }^{3}$ MLCT emission was quenched due to entrapment of the complex within the protein environment. The association and/or interaction of $\operatorname{Re}(\mathrm{I})$ compound with the amino acid residues of the polypeptide 
chain of BSA induced a conformational change of the secondary structure of the protein with a decrease of its $\alpha$-helicity [90].

\subsection{Mitochondrial effects of $\operatorname{Re}$ complexes}

$\operatorname{Re}(\mathrm{CO})_{3}$ complexes, especially those with highly lipophilic ligands (e.g., 4,7-diphenyl-1,10phenanthroline), can localize to mitochondria of cancer cells as evidenced by confocal microscopy taking into profit the luminescent properties of many Re compounds [91]. If the binding of Re to mitochondrial DNA remains to be demonstrated, the relationship between Re compounds and mitochondria may be of great importance. Using a ferrocenyl ancillary ligand with quenching properties it has been shown that the fac- $\left[\operatorname{Re}(\mathrm{CO})_{3}(\text { phen })\right]^{+}$cationic moiety having lost its axial ligand rapidly reacted with various cellular matrix molecules giving secondary products, which are uptaken into the negatively charged mitochondrial membranes [92]. Likewise, using a reactive 3-chloromethylpyridinium ancillary ligand it was shown that 4,7-diphenyl-1,10-phenanthroline $\operatorname{Re}(\mathrm{CO})_{3}$ complexes efficiently accumulated in mitochondria of A549 cancer cells presumably by reaction with thiol groups. The mitochondrial immobilization resulted in greater cytotoxic effect than cisplatin. The damages induced by the Re complex directly affected mitochondrial respiratory activity [93]. Likewise, the mitochondrial respiratory activity in MCF-7 breast cancer cells was the direct target of a highly cytotoxic $N, N^{\prime}$-bis[(quinolin-2-yl)methyl]amine Re complex 14 bearing an azido ethyl appendage. Mechanism of action studies clearly showed that mitochondrial respiratory activity was a direct target of this complex according to two modes of action, namely an increased respiration at lower concentrations and an efficient blocking of respiration at higher concentrations [94]. The mitochondria-accumulating binuclear $\operatorname{Re}(\mathrm{I})$ tricarbonyl complexes $\mathbf{1 3}$ in which two $\operatorname{Re}(\mathrm{CO})_{3}$ subunits were bound together through a 4,4'-azopyridine linker were recently identified. This compound inhibiting tumor growth in vivo was found to cause oxidative stress and mitochondrial dysfunction, inducing necroptosis and caspase-dependent apoptosis simultaneously [95] (Fig. 3). 
There is now an evidence that Re compounds accumulate in mitochondria, but their binding to a drug can overcome the normal uptake pathway of this drug as it was shown for doxorubicin which is diverted of its normal accumulation in the nucleus to mitochondria by binding a $\mathrm{CpRe}(\mathrm{CO})_{3}$ subunit to the sugar moiety [96].

\subsection{Rhenium complexes and oxidative stress}

Oxidative stress resulting of excessive reactive oxygen species (ROS) production unbalanced by inadequate reductive mechanisms was related to cell proliferation, differentiation, and apoptosis. Oxidative stress could trigger apoptosis via both the mitochondria-dependent and mitochondriaindependent pathways. Many $\operatorname{Re}(\mathrm{I})$ complexes were found able to reduce ROS production even at a low concentration. For example, the $\operatorname{Re}(\mathrm{CO})_{3}$ complexes with 2-acetylpyridine-derived hydrazones ligand that showed antiproliferative activity against NCI-H460 human large cell lung cancer decreased the production of ROS according to a non-mitochondrial pathway [97]. In connection with PDT it must be noticed that MLCT excited states of $\operatorname{Re}(\mathrm{I})$ polypyridyl complexes displayed a significant oxidizing power able to generate tyrosyl radical. Furthermore, the excited-state oxidation potential was increased by introducing a monodentate phosphine. The rate constant for tyrosyl radical generation was consistent with a protoncoupled electron transfer (PCET) quenching mechanism [98]. 


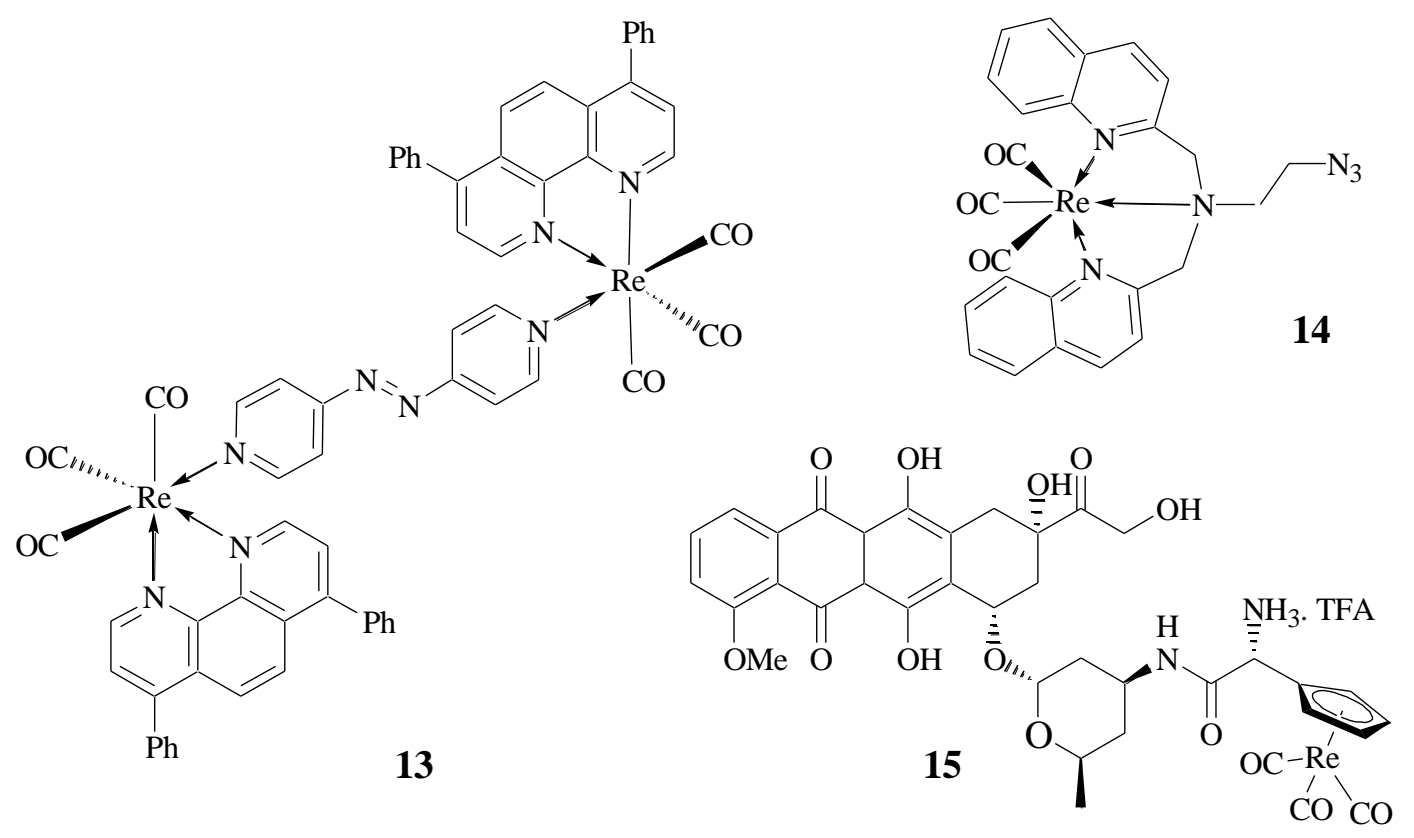

Fig. (3). Representative rhenium complexes for mitochondrial targeting.

The power of oxidation of $\operatorname{Re}(\mathrm{I})$ diimine carbonyl complexes increased with the lifetime of the ${ }^{3}$ MLCT excited state which can be modulated by introducing interligand interactions with aromatic ligands or by ring-shaped multinuclear $\operatorname{Re}(\mathrm{I})$ complexes [42].

Di-Re (III) cluster compounds showed antioxidant properties protecting red blood cells from hemolysis in experimental models [99-103]. Accordingly, it has been proposed to use $\operatorname{Re}(\mathrm{III})$ to protect red blood cells from the toxicity of cisplatin [104].

A highly significant synergism has been observed between dichlorotetra- $\mu$-isobutyratodirhenium (III) complexes and cisplatin in tumor-bearing Wistar rats, transplanted with T8 Guerin's carcinoma cells, with a nearly complete regression of the tumors. These remarkable anticancer properties were associated with a strong anti-oxidant effect, with a decrease in lipid peroxidation (LP), as shown by a decrease in plasma concentrations of thiobarbituric active substances (TBA) and an increase of the activity of superoxide dismutase (SOD) in erythrocyte hemolysates [105].

Recently, luminescent $f a c$ - $\left[\operatorname{Re}(\mathrm{CO})_{3}(\right.$ phen $\left.)\right]$ carboxylato complexes were coupled to aspirin and some nonsteroidal antiinflammatory drug (NSAID) carboxylates. The aspirin complex displayed some promising 
activity specially on HeLa cells. The activity was correlated to the increase of ROS levels in HeLa cells and had a substantial influence on the cell cycle, increasing number of cells in the sub-G1 and S phases [106].

\subsection{Effect of rhenium complexes on enzymatic activities}

Many Re complexes alone or tethered to labeling moieties were designed to recognize various targets in the cell as depicted in Table 1. Thiol-containing enzymes such as the redox enzymes thioredoxin reductase, glutathione reductase, and cysteine proteases such as caspases and cathepsins are a potential target for metallodrugs. The interaction of these enzymes with $\operatorname{Re}(\mathrm{V})$ oxorhenium complexes has been reviewed. The catalytic mechanism of these enzymes was depending on a cysteine at the active site. A hypothetical model of compound binding was constructed with the Re inhibitor being coordinated to the active site cysteine after ligand substitution of the monodentate ligand [107]. Re-based protease inhibitors are mainly $\operatorname{Re}(\mathrm{V})$ complexes, nevertheless, an epoxysuccinyl-based inhibitor decorated by a luminescent $\operatorname{Re}(\mathrm{I})$ tag has been recently synthesized a showed to inhibit cathepsin $\mathrm{L}$ in the low-nanomolar range. Characterization of the product obtained by reaction with papain revealed that the $\operatorname{Re}(\mathrm{I})(\mathrm{phen})(\mathrm{CO})_{3}$ metal fragment remained intact upon covalent modification of papain [108]. Another example of Re luminescent tag associated to a targeting head was described by Ye et al. who covalently coupled standard 4,7diphenyl-1,10-phenanthroline $\operatorname{Re}(\mathrm{CO})_{3}$ to the histone deacetylase inhibitor SAHA [109].

A dichlorotetra- $\mu$-isobutyratodiRe (III) complex was found highly effective in inhibition of the lipid peroxidation. In vitro, it was shown to activate the active center of native superoxide dismutase [105].

A series of $\mathrm{CpRe}(\mathrm{I})(\mathrm{CO})_{3}$ compounds harboring a piperazine side chain on the $\mathrm{Cp}$ ring was found moderately active on HT-29 cancer cells. Based on computational studies, inhibition of the GSK-3 $\beta$ was postulated to be involved in the cytotoxic activity of these complexes [110]. 
An array $p$-hydroxyphenyl-substituted $\mathrm{CpRe}(\mathrm{CO})_{3}$ complex was evaluated for binding to estrogen receptors (ER). Among them, aryl-substituted $\mathrm{CpRe}(\mathrm{CO})_{3}$ complexes were found to bind to the ER with affinity as great as $20 \%$ of the native ligand, estradiol. The high affinity complexes indicates that the bulky $\operatorname{Re}(\mathrm{CO})_{3}$ unit filled the considerable volume in the center of the ER ligand binding pocket that was not occupied by most ligands, a consideration that is supported by molecular modelling as illustrated in Fig. 4. Analysis of the interactions of the ligand with the surface of the cavity suggested that the enantiomer in Fig 4C suffered from fewer constraints than the antipode in Fig. 4D (marked as purple dots). Although the actual product is a racemic this study clearly suggested that it might be useful to prepare these Re complexes as homochiral derivatives. When compared the ligands the complexes exhibited the right fit in the ER with high affinity. This study further suggested that the binding to the pocket of the ER was due to the bulkiness of rhenium metal. However, the functional substituents of alkyl and hydroxyphenyl containing ligand are reported to have shown the covalent interactions and weak interactions with leucine, histidine and glutamate residues found on the binding pocket of the ER [111].
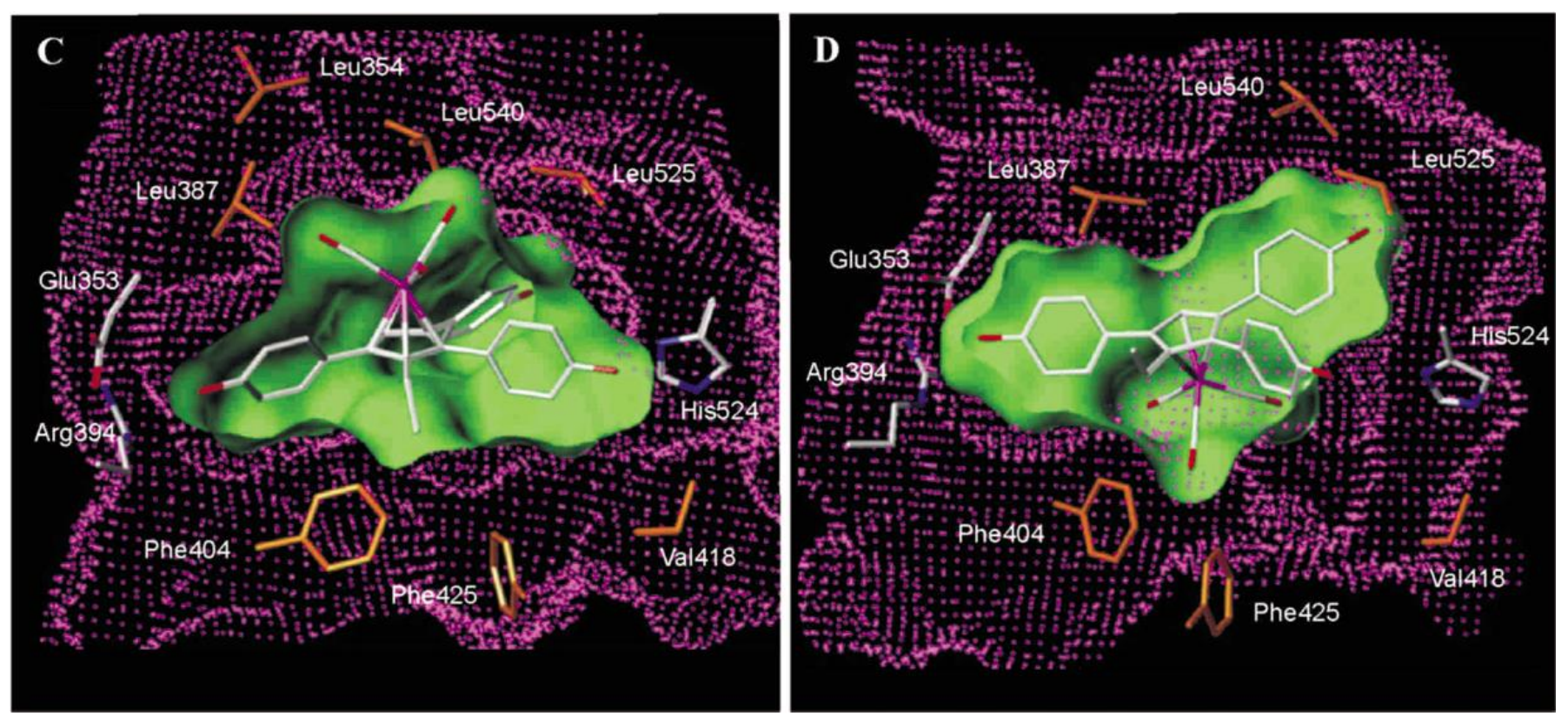

Fig. (4). Docking of both enantiomers of a $p$-hydroxyphenyl-substituted $\mathrm{CpRe}(\mathrm{CO})_{3}$ complex in the estrogen receptor ERa ligand binding pocket. Reproduced with the permission of ref. [111] 
The binding properties of these novel Re based organometallic complexes were studied with the help of combination of Comparative Molecular Similarity Indices Analysis (CoMSIA) and docking studies. A total of 11 rhenium complexes and 18 organic ligands were docked inside the ligand-binding domain of ER $\alpha$ utilizing the program Gold. The combined CoMSIA and polar volume model ranked correctly the ligands in order of increasing relative binding affinities, illustrating the utility of this method as a prescreening tool in the development of novel Re--based estrogen receptor ligands [112]. (2Pyridyl)hydrazono- $\operatorname{Re}(\mathrm{CO})_{3}$ complex bound to the potent natural estrogen $17 \beta$-estradiol through a ethynyl linker was synthetized as a potential probe for targeting estrogen receptors $[113,114]$. Likewise, a folate receptor probe was designed by coupling $\left\{[\right.$ bis(quinolin-2-ylmethyl)amino]-5-valeric acid $\} \operatorname{Re}(\mathrm{CO})_{3}$ with folic acid[115]. The coupling of $\operatorname{Re}(\mathrm{CO})_{3}$ moiety with platelet activating factor (PAF) receptor antagonists [116], benzenesulfonamide based carbonic anhydrase IX inhibitors [117], G protein-coupled estrogen receptor inhibitors [118], myristoylated Tat peptide improving the cell membrane permeability [119] has also be reported.

The modification of a peptide with a 2-((pyridin-2-yl-methyl) group afforded a tridendate ligand able to tightly complex the $\operatorname{Re}(\mathrm{CO})_{3}$ core. This widely applicable chelation strategy was exemplified by the incorporation of the $\left[\operatorname{Re}(\mathrm{CO})_{3}\right]^{+}$moiety into $\alpha$-melanocyte stimulating hormone $(\alpha \mathrm{MSH})$ peptide analogues, which target the melanocortin 1 receptor (MC1R) on melanoma cells [120]. There were much fewer examples with the higher oxidation degrees of Re. OxoRe(V) complexes bearing 3,3'thiodipropanethiol tridentate ligands showed remarkable inhibitory activity for both cathepsin B and K [121].

\subsection{Interaction of rhenium complexes with signaling pathways}

A series of mono-and multinuclear polypyridine cationic $\operatorname{Re}\left(\mathrm{CO}_{3}\right)$ complexes was found to inhibit epithelial carcinoma (A431), colon carcinoma (DLD-1) and ovarian cancer cell line (A2780). Studies showed that these complexes influenced the programmed cell death mechanisms in vitro, inhibiting the 
soluble form of the Fas receptor in tumour cell lines with a selective cytotoxicity versus a healthy fibroblast $(\mathrm{BJ})$ cell line [122].

$\operatorname{Re}(\mathrm{CO})_{3}$ complexes containing N-heterocyclic carbene (NHC) ligands and conjugated to indomethacininduced cell cycle arrest at the G2/M phase by inhibiting the phosphorylation of Aurora-A kinase in pancreatic cell lines, with a remarkable activity of the Re fragment by comparison with Ru complexes with the same ligands [123]. $\operatorname{Re}(\mathrm{CO})_{3}$ complexes containing the nitric oxide synthase (NOS) inhibitor $\mathrm{N}^{\omega}{ }_{-}$ nitro-l-arginine suppressed NO biosynthesis in lipopolysaccharide-treated macrophages. The Re complexes with flexible propyl- and hexyl spacer exhibited remarkable affinity for purified iNOS. These results were validated by using the RAW 264.7 cell line in which Re complexes could permeate through cell membranes, interacting specifically with the target enzyme. Molecular docking study combined with dynamic simulations and free energy perturbation calculations were used to evaluate the complexes. The results revealed that the main interaction arose from the strong electrostatic interactions between the $\operatorname{Re}(\mathrm{CO})_{3}$ core and the Arg260 and Arg382 residues [124]. The complex was evaluated for in vivo imaging of nitric oxide synthase (NOS). Biodistribution studies have been performed in LPS-pretreated mature female C57BL6 mice and a high uptake was observed in lungs, the organ with the highest iNOS expression [125].

Table 1. Rhenium complexes and their potential reported targets in experimental models

\begin{tabular}{|l|l|l|l|}
\hline $\begin{array}{l}\text { Rhenium } \\
\text { complex }\end{array}$ & In vitro /in vivo models & Targets & References \\
\hline $\begin{array}{l}\text { Mono and } \\
\text { dinuclear } \\
\text { complexes }\end{array}$ & $\begin{array}{l}\text { In vitro A431, DLD-1, } \\
\text { A2780 cell lines }\end{array}$ & Fas receptors & 122 \\
\hline $\begin{array}{l}\text { Indomethacin- } \\
\operatorname{Re}(\mathrm{CO})_{3} \\
\text { conjugated }\end{array}$ & $\begin{array}{l}\text { Pancreatic cancer cell } \\
\text { lines }\end{array}$ & $\begin{array}{l}\text { Aurora kinase, G2/M } \\
\text { arrest }\end{array}$ & 123 \\
\hline $\begin{array}{l}\text { CpRe(I)(CO) })_{3} \\
\text { Re(CO) })_{3} \text { NOS } \\
\text { inhibitors }\end{array}$ & Nil cell lines & Estrogen receptors & $111,112,114,118$ \\
\hline Neutral, cationic & SKNMC cell lines & Thymidine kinase & 126,128 \\
\hline
\end{tabular}




\begin{tabular}{|l|l|l|l|}
\hline $\begin{array}{l}\text { and anionic } \\
\text { complexes of } \\
\operatorname{Re}(\mathrm{I})(\mathrm{CO})_{3}\end{array}$ & & \\
\hline $\begin{array}{l}\text { Folic-acid } \\
\operatorname{Re}(\mathrm{I})(\mathrm{CO})_{3}\end{array}$ & $\begin{array}{l}\text { FR-overexpressing } \\
\text { A2780/AD cell line }\end{array}$ & Folate receptor & 115 \\
\hline $\begin{array}{l}\text { Rhenium } \\
\text { diselenium } \\
\text { complex }\end{array}$ & MDA MB-231 cell lines & $\begin{array}{l}\text { ROS, TG } \beta, \text { TNF- } \alpha, \\
\text { IL-6 }\end{array}$ & $21,159-161$ \\
\hline
\end{tabular}

Neutral, cationic, and anionic (thymidine $) \operatorname{Re}(\mathrm{I})(\mathrm{CO})_{3}$ complexes were designed to inhibit the activity of human thymidine kinase 1 (hTK-1). The highest toxicity on malignant cells was observed for the complex with a dodecylene spacer at C5'. A low uptake was observed for the charged complexes but the uptake was significant for the neutral, lipophilic complexes [126-128]. A new cationic (bisphenanthridine) $\operatorname{Re}(\mathrm{CO})_{3}$ complex showed promising antiproliferative activity in low micromolar concentrations on a variety of cancer cells with excellent selectivity for cancer versus non-cancer cells. Resistance-breaking profiling and gene expression analysis on an organometallic (phenanthridine $)(\mathrm{CO})_{3} \mathrm{Re}$ complex revealed parallel activation of two apoptotic pathways [129].

\section{CELL EFFECTS}

\subsection{Cell uptake and localization of Rhenium complexes}

The relationship between the chemical structure of Re compounds and their subcellular localization is a major stake to understand their mechanism of action. We already discussed the mitochondrial uptake of Re complexes (see section 3.3). In a comparison of series of mononuclear and dinuclear $\operatorname{Re}(\mathrm{CO})_{3}$ compounds, it was found that complexes with lower lipophilicity were localized in lysosomes and induced caspase-independent apoptosis, whereas Re-complexes with higher lipophilicity especially accumulated in mitochondria and induced caspase-independent paraptosis in cancer cells [130]. The localization of Re in cell appeared to be driven mainly by the nature of the ligand, for example, $\operatorname{Re}(\mathrm{I})$-chromone bioconjugate was localized in the cytoplasm, mitochondria, and endoplasmic reticulum in mouse $\mathrm{C} 2 \mathrm{C} 12$ cancer cells 
[131]. On the other hand, the cytotoxic activity of benzothiazoletethered $\operatorname{Re}(\mathrm{I})(\mathrm{CO})_{3}$ complexes stabilized by a cysteamine-based $(\mathrm{N}, \mathrm{S}, \mathrm{O})$ chelator was well correlated with cellular uptake and fluorescence microscopy, clearly confirming their cytosolic accumulation [132].

$\operatorname{Re}(\mathrm{CO})_{3}$ complexes based on tridentate phenanthridine-containing ligands were localized in the endoplasmic reticulum of several cancer cell lines [47] whereas a pyrido-triazole $\operatorname{Re}(\mathrm{CO})_{3}$ with a pendant azido alkyl chain was localized to the Golgi apparatus in MDA-MB-231 breast cancer cells [133]. A closely related tetrazolato $\operatorname{Re}(\mathrm{CO})_{3}$ complexes had a diffuse reticular localization in the nuclear/perinuclear region of cells and induced disruption of the homeostasis of chlorine, potassium and zinc [134].

$\operatorname{Re}(\mathrm{CO})_{3}$ complexes with zwiterionic $p$-nitrophenyl pyridylhydrazone ligands displayed higher uptake in hypoxic HeLa cells than in normoxic cells and the cationic complex fac- $\left[\operatorname{Re}(\mathrm{CO})_{3}(\mathrm{~L})\right]^{+}$where $\mathrm{L}$ is a nitroimidazole ring, has a 5-fold increased retention in hypoxia-induced cells [135]. High valent (ReVI) octahedral Re cluster complexes, conjugated with a polymer, were taken up by human cervical adenocarcinoma HeLa cells in a concentration-dependent manner and were localized in the cytoplasm and nucleus upon incubation, but did not exhibit acute cytotoxic effects up to $50 \mu \mathrm{M}$ [136].

\section{Table 2. Reported cellular localization of various Re complexes}

\begin{tabular}{|l|l|l|l|}
\hline Types of rhenium complexes & Cellular localisation & $\begin{array}{l}\text { In vitro /in vivo } \\
\text { models used }\end{array}$ & Reference \\
\hline Re(I)-chromone bisconjugate & $\begin{array}{l}\text { Cytosol, } \\
\text { mitochondria and } \\
\text { endoplasmic } \\
\text { reticulum }\end{array}$ & $\begin{array}{l}\text { Mouse C2C12 } \\
\text { cancer cells }\end{array}$ & 131 \\
\hline $\begin{array}{l}\text { Benzothiazole- } \operatorname{Re}(\mathrm{I})(\mathrm{CO})_{3} \\
\text { stabilised by cysteamine }\end{array}$ & Cytosol & $\begin{array}{l}\text { Human breast cancer } \\
- \text { MCF7, prostate } \\
\text { cancer - PC3 - cell } \\
\text { lines. }\end{array}$ & 132 \\
\hline Phenanthridinyl Re & $\begin{array}{l}\text { Endoplasmic } \\
\text { reticulum }\end{array}$ & Several & 47 \\
\hline $\operatorname{Re}(\mathrm{I})(\mathrm{CO})_{3}$ derivatives & Golgi apparatus & $\begin{array}{l}\text { MDA MB-231 cell } \\
\text { line }\end{array}$ & 133 \\
\hline
\end{tabular}




\begin{tabular}{|l|l|l|l|}
\hline $\begin{array}{l}\text { Tetrazolate } \operatorname{Re}(\mathrm{I})(\mathrm{CO})_{3} \\
\text { complexes }\end{array}$ & $\begin{array}{l}\text { Endoplasmic } \\
\text { reticulum and } \\
\text { perinuclear space }\end{array}$ & $\begin{array}{l}\text { 22Rv1 human } \\
\text { prostate epithelial } \\
\text { carcinoma cells }\end{array}$ & 134 \\
\hline $\begin{array}{l}p \text {-Nitrophenylhydrazone- } \\
\text { pyridyl ligands }\end{array}$ & Cytosol & Hela cell line & 135 \\
\hline
\end{tabular}

\subsection{Inhibitory and cytotoxic effects of rhenium complexes. Mode of cellular deaths.}

The cytotoxic effects of many $\operatorname{Re}(\mathrm{I})(\mathrm{CO})_{3}$ compounds with the concentrations inhibiting the growth of $50 \%\left(\mathrm{IC}_{50}\right)$ of many types of cancer cells were reviewed in 2014 by Leonidova and Gasser. Most $\operatorname{Re}(\mathrm{I})$ complexes had inhibitory effects on malignant cells, with an $\mathrm{IC}_{50}$ lower than $100 \mu \mathrm{M}$ for an exposure time of $48 \mathrm{~h}$ [16]. Several death pathways were observed with Re-based anticancer drugs. A large number of $\operatorname{Re}(\mathrm{CO})_{3}$ complexes induced apoptosis while a paraptotic mechanism, caspase-independent, with enlarged mitochondria, production of ROS, and cytoplasmic vacuolization has been observed when histone deacetylase inhibitor were coordinated to the axial position of the $\operatorname{Re}(\mathrm{CO})_{3}$ scaffold. Paraptotic cell death was mainly observed with compounds accumulating in the mitochondria, and apoptosis with compounds localized in the lysosome [18]. (Phen) $\operatorname{Re}(\mathrm{CO})_{3}$ cationic aqua complexes with $\mathrm{IC}_{50}$ values less than $20 \mu \mathrm{M}$ in HeLa cells induced cytoplasmic vacuolization and were also effective in cisplatin-resistant cells in wild-type cells [137].

Labile ligand on the metal center can play a major role, for example the chlorido derivative of oximine $\mathrm{Re}$ (I) complexes were more efficient than bromido derivative to induce apoptotic cell deaths of human A375 melanoma and K562 leukemia cells, while the free ligand did not show any significant anticancer activity [138]. Pyridino- and quinolino-triazolo $-\operatorname{Re}(\mathrm{CO})_{3}$ complexes conjugated with a glutamine appendage exhibited absorptions in the 300-400-nm range with MLCT character, as predicted by TD-DFT calculations. They were found nontoxic over a large concentration range (0-1.4 mM) on HT-29 human colon adenocarcinoma cell line, even though a significant concentration-dependent uptake was observed at 3 and $24 \mathrm{~h}$ for one of them [139]. Similarly, glycoconjugates of mononuclear Re (I) carbonyl complexes with pyridyltriazole ligands have been prepared with coordination of the metal ion by both pyridyl and 
triazol nitrogen atoms. All sugar-functionalized complexes were found to be nontoxic against HepG2 cells at concentration of $100 \mu \mathrm{M}$, except for the complex derived from the pyridyl (tert-butylbenzyl)-triazole, which exhibited remarkable toxicity [140].

Rhenium (IV) compounds induced apoptosis in cancer cells [28] while $\operatorname{Re}(\mathrm{V})$ oxo complexes killed cancer cells by a non-apoptotic pathway involving a necroptotic mode of programmed cell death, depending on the intracellular production of ROS with a mitochondrial membrane potential depletion [30].

\subsection{Selectivity of rhenium compounds for cancer cell lines}

The selectivity of Re compounds for cancer cell lines is one of the main advantages over other organometallic drugs such as platinum compounds that suffer from strong side effects. For example, pentylcarbonato $\operatorname{Re}(\mathrm{CO})_{3}$ compounds induced significant cytotoxic effects at the dose of $10 \mu \mathrm{M}$ for an exposure time of 48h in HTB-12 human astrocytoma brain cancer cells but not against CRL-2005 rat astrocyte normal brain cells [78]. $\operatorname{Re}(\mathrm{CO})_{3}$ acetylsalicylato complexes showed a very selective cytotoxicity on HTB-12 human astrocytoma brain cancer cell lines and glioblastoma multiforme D54 cell lines versus rat normal brain astrocyte cells [77]. Similarly, (salicylaldehyde semicarbazone) $\operatorname{Re}(\mathrm{CO})_{3}$, that

was found to react with DNA guanosine by proton transfer from the phenolic OH group to N7 of guanosine, selectively induced apoptosis against MOLT-4 cells versus normal human fibroblasts [141].

Selective and dose-dependent inhibitory effects were observed with Re (I) based metallacrown ethers on cancer-lung (A549), breast (MCF-7), colon (HCT-15), cervical (HeLa), liver (HepG2) and leukemia (K562) cells versus normal blood mononuclear cells (PBMCs) [142]. Similarly, the aforementioned cluster $\left[\operatorname{Re}_{6} \mathrm{Se}_{8} \mathrm{I}_{6}\right]_{3}$ - induced preferential cell death of a hepatic carcinoma cell line $[39,143]$.

\section{METABOLISM, PHARMACOLOGY AND TOXICOLOGY OF RHENIUM COMPLEXES}

According to the small number of in vivo experiments with cold Re complexes only a few data are available. However, some data on ${ }^{188}$ Re radiopharmaceuticals are available. For example, The metabolism 
of (carboxycyclopentadienyl)[188Re](CO)3 and its glycine conjugate has been studied after administration into mice. The (carboxycyclopentadienyl) [188Re](CO)3 was more lipophilic and excreted by both hepatobiliary and urinary excretion. The majority of the less lipophilic glycine conjugate was excreted by urinary excretion, as its intact structure [144]. B12-ReII(CO)2 derivatives obtained by conjugation of $\operatorname{Re}(\mathrm{II})(\mathrm{CO}) 2$ complex to cyanocobalamin (B12) have been proposed as CORMs to improve the stability of the metal complex alone. After $\mathrm{CO}$ release, the oxidation of the metal resulted in the formation in solution of the $\mathrm{ReO} 4-$ anion, which was considered by the authors to be among the least toxic of all of the rare inorganic compounds [145].

\section{ANTITUMOR ACTIVITIES OF RHENIUM COMPLEXES IN ANIMAL EXPERIMENTS}

There are still few experiments of Re complexes in tumour-bearing animals. Nevertheless, impressive results have been obtained by Shtemenko et al. with di-Re (III) compounds decorated with various carboxylate ligands such as GABA (III)-di-Re [146], dichlorotetra- $\mu$-isobutyrato-di-Re(III) [147] and Rediadamantate [148]. Liposomal forms of these Re compounds were intraperitoneously (IP) injected in Wistar rats, every 2 days, at the dose of $7 \mu \mathrm{M} / \mathrm{kg}$ from day 3 after the inoculation of Guerink malignant cells until day 21 . Re compounds alone did not produce significant antitumor activities versus the control groups, receiving no treatment. Cisplatin significantly reduced the tumor volumes versus the control groups, but a high synergistic effect was observed with the combination of cisplatin and all three $\mathrm{Re}$ compounds, with a nearly disappearance of the tumors in the case of the dichlorotetra- $\mu$-isobutyrato-di$\operatorname{Re}(\mathrm{III})$ complex. The formulations, modes of administration, combination with cisplatin of the latter complexes were extensively studied. They were administered as liposomes, nanoliposomes, solid nanoparticles or in water solution in tumor-bearing Wistar rats, transplanted with T8 Guerin's carcinoma cells. In a group of rats receiving a combination of dichlorotetra- $\mu$-isobutyratodirhenium (as liposomal form) and cisplatin (as an IP administration), the average tumor volume decreased significantly in respect to the control but also compared to the tumor treated by cisplatin[105]. Another di-Re compound bearing 
two ancillary DMSO ligands (bis-dimethylsulfoxido-cis-tetrachlorodi- $\mu$-pivalato)-dirhenium(III) has also been studied [83]. Excellent results were obtained with nanoliposomes loaded with both this pivalatodirhenium(III) complex and cisplatin in the molar ratio of 4:1 [149]. However, liposomes loaded with both drugs were not as stable as those loaded with only the di-Re complex. A full account of the antitumor experiments conducted with Re (III)/Pt antitumor synergistic systems has been written by Shtemenko et al. highlighting the crucial role of the strong antiradical and antioxidant properties embedding in the quadruple Re-Re bond [150].

A new cationic 1-(2-quinolinyl)- $\beta$-carboline $\mathrm{Re}(\mathrm{CO})_{3}$ complex with a $\mathrm{pH}$-dependent phosphorescence reduced of $60 \%$ the tumor volume in A-549 xenografted nude mice. Mechanism studies showed that this complex can induce autophagy leading to apoptosis dependent cell death. The impairment of the autophagy-related lysosomal degradation pathway is unusual with metallodrugs [151]. PDT experiment on MCF-7 tumor-bearing nude mice with a (rhodamine-conjugated dipy) $\operatorname{Re}(\mathrm{CO})_{3} \mathrm{Br}$ complex showed remarkable tumor growth inhibition upon irradiation with a xenon lamp light source after injection. It has been proposed that generation of triplet excited state of a rhodamine moiety endowed the complexes with mitochondria-targeting photosensitizing ability to form ${ }^{1} \mathrm{O}_{2}$ species [152].

\section{SCHEMATIC REPRESENTATION OF THE BIOLOGICAL EFFECTS OF RHENIUM COMPOUNDS}

Considering all the previous cited studies, we propose the following schematic representation of all the biological effects of Re complexes (Figure 5): 


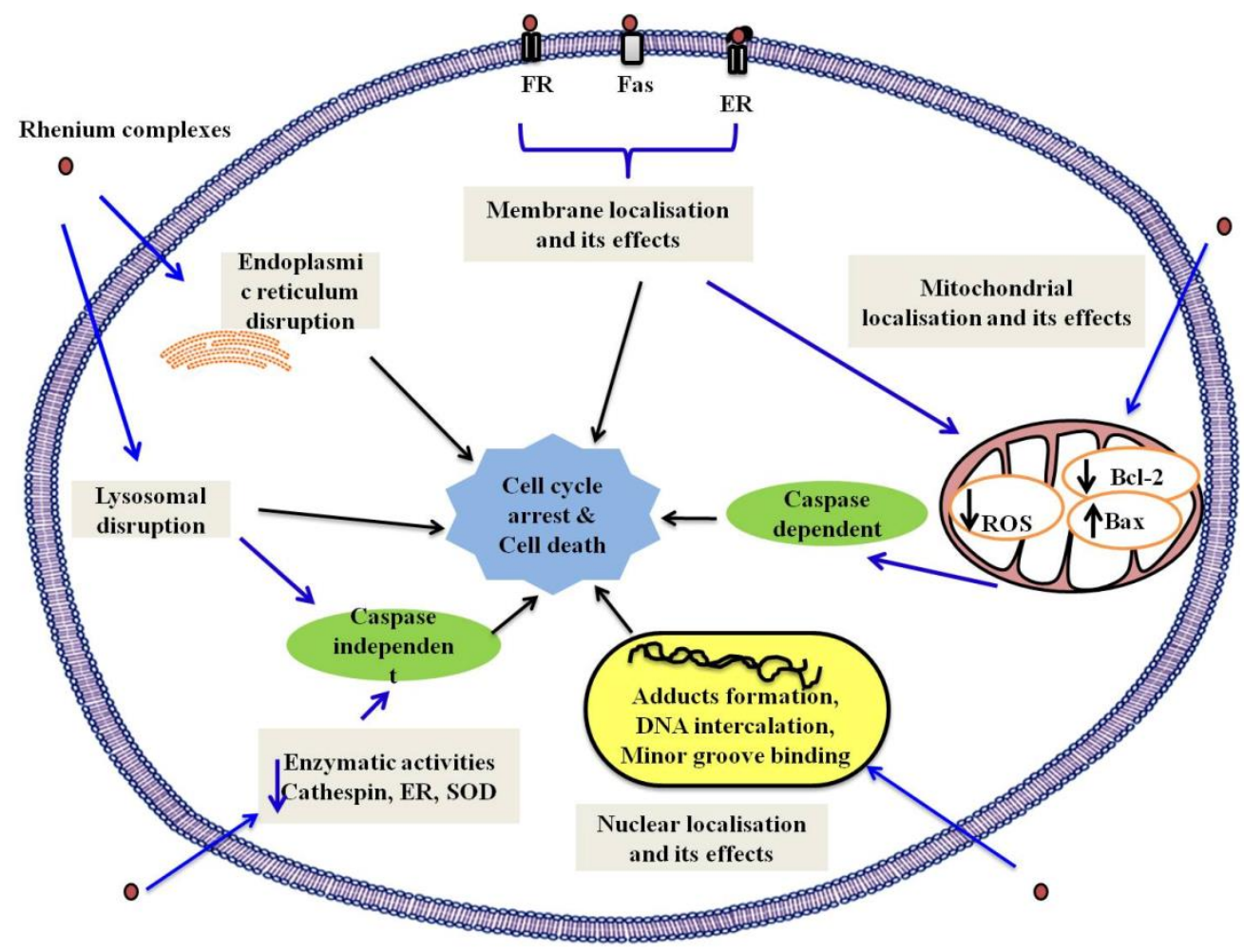

Fig. (5): Re complexes may induce many biological effects and efforts remain to be made to select one compound as a targeted therapy with one or two specific targets, a great selectivity for cancer cells, a good biodistribution and oral availability, a favourable therapeutic index and the possibility to monitor the treatment by the help of biomarkers.

\section{DESIGN OF A SELECTED RHENIUM COMPOUND AS A TARGETED THERAPEUTIC}

\section{ANTICANCER DRUG}

\section{We propose the $\operatorname{Re}(\mathrm{I})$-diselenoether complex as a selected compound}

\subsection{Chemical and physico-chemical data of the rhenium(I)-diselenoether complex}

The $\operatorname{Re}(\mathrm{I})$-diselenoether sodium salt (Re-diSe, Fig. 6) in which a central inorganic Re atom is coordinated by two Se atoms has the advantage to be both soluble in water and lipophilic with a good diffusion of the 
two elements, Re and Se into the tissues after an oral administration. Re-diSe is among the Re compounds with the most detailed preclinical studies to date. The acidic form is obtained by simple displacement of two carbon monoxide molecules of $(\mathrm{CO})_{5} \mathrm{ReCl}$ with 3,7-diselena-azelaic acid. The Re-diSe is simply obtained by sodium hydroxide treatment of the corresponding di-acid. The structure of both compounds has been fully determined by IR, NMR, MS and elemental analysis. The chair-like conformation of the SeReSe ring has been deduced from the X-Ray crystal structure of the closely related analogue bearing a phenyl group on both Se atoms [20]. By analogy, Re-thiolate compounds have been investigated and the conclusions can at least partially be expanded to the closely related Re-selenolates. The studies showed that the sulfur atom in Re-thiolate complexes displayed a partial nucleophilic character [153]. This reactivity of the thiolate has been attributed to the interaction of the sulfur $\mathrm{p}$ lone-pair with a "t $2 \mathrm{~g}$ " metal $\mathrm{d}$-orbital. When the metal d-orbital and sulfur $\mathrm{p}$ lone-pair had similar energies, there was a strong interaction that yielded a significantly stabilized $\pi$-bonding orbital and a significantly destabilized $\pi$-antibonding orbital. Each of these orbitals had significant sulfur and metal character. Although there was no net $\pi$-bond, the increased energy of the anti-bonding orbital "activated" the thiolate nucleophilicity. In the case of Re-selenolate, the same type of interaction between Re (I) and Se could also increase the selenolate nucleophilicity.
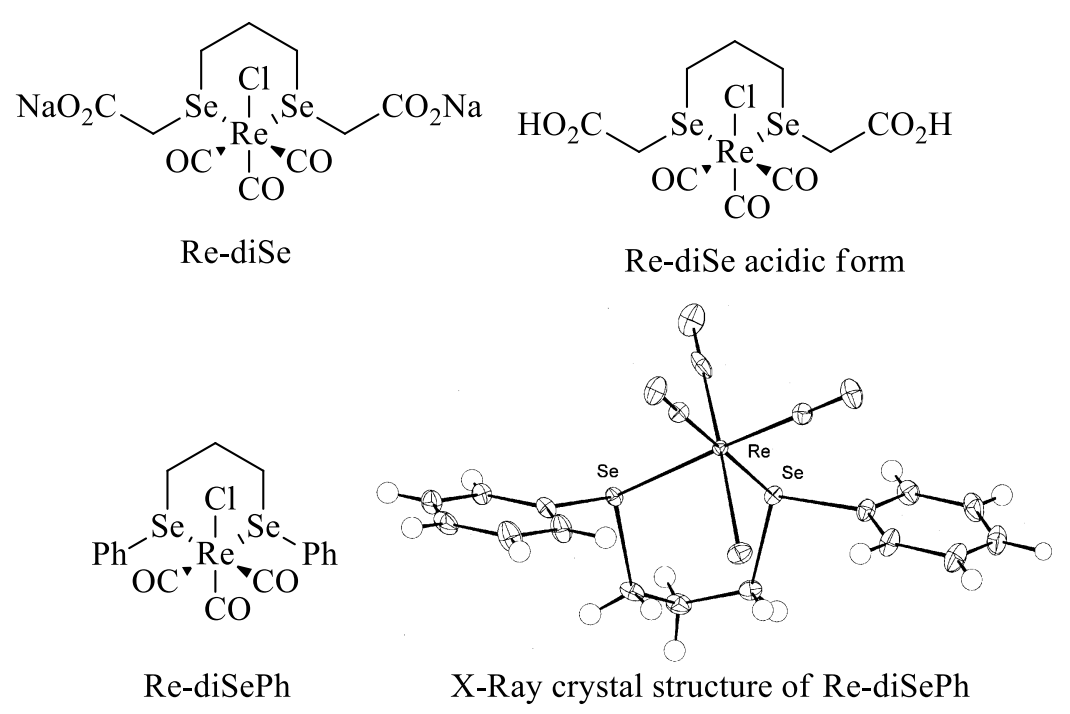
Fig. (ㅁ). Chemical structures of the sodium salt and acidic forms of Re-diSe. X-Ray crystal structure of Re-diSePh

\subsection{Biological effects of the rhenium(I)-diselenoether complex}

\subsubsection{Interaction with DNA}

To investigate a possible interaction of Re-diSe with DNA bases, the binding of Re-diSe as its dimethyl ester form with 9-methylguanine (9-MeG) has been investigated. Formation of covalent adducts has been identified by mass spectroscopy. Thus, the whole $\operatorname{Re}(\mathrm{I})(\mathrm{CO})_{3}$-diSe complex could bind one guanine base, as represented in Fig. 7 but a methylguanine bis-adduct ion (B) can also be observed as well as a deliganded monoadduct species (C) [21].

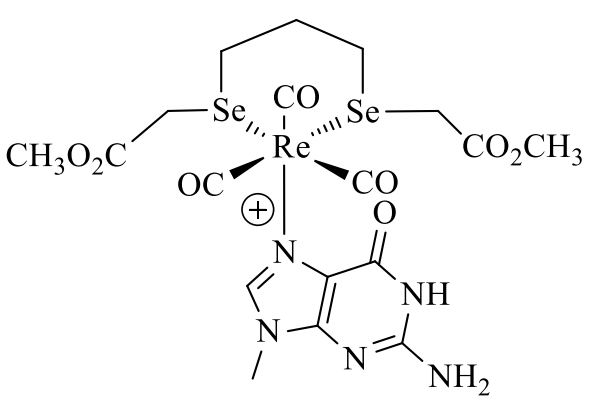

A

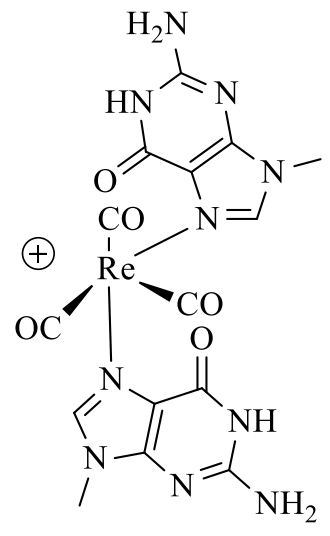

B

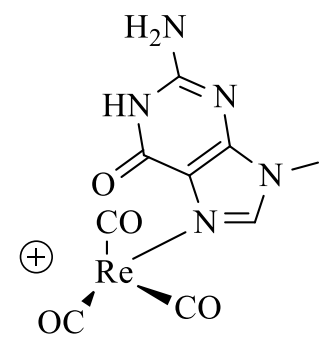

C

Fig. (7). 9-Me-guanine/ Re-diSe adducts identified by mass spectrometry The following figures, in chapter 7, are in Open Access, in supplementary material of a paper published in Investigational New Drugs and may be used according to the Creative Commons license, (http://creativecommons.org/licenses/by/4.0/).

As for other Re compounds, it is expected that the binding of Re with DNA would be reversible. Due to the well described mitochondrial localization of Re into mitochondria, Re could bind not only in the nucleus of the cells, but also with the mitochondrial DNA which is the main site of production of ROS. 
The ligand di-Se as well as Re could then induce their major effect which could be on the ROS production.

\subsubsection{Effects of the rhenium(I)-diselenoether complex on the production of ROS}

In fact, it has been demonstrated that the Re-diSe drug was able to significantly decrease the production of ROS in MDA-MB231 hormone-independent breast cancer cells [154], at the dose of $5 \mu \mathrm{M}$ for an exposure time of $120 \mathrm{~h}$, while the normal human embryonic kidney HEK-293 cells were not affected, except at the highest dose of $200 \mu \mathrm{M}$. The decreased production of ROS in cancer cells was dosedependent. At the dose of $200 \mu \mathrm{M}$, the levels of ROS in cancer cells reached those observed in non-treated HEK-293 normal cells.

As a consequence, the decrease of the ROS production will induce a down-regulation of major signaling pathways.

\section{8-2.3. Effects of the rhenium(I)-diselenoether complex on signaling pathways}

Effectively, the Re-diSe drug was able to significantly decrease the production of IGF-1, VEGF-A and TGF- $\beta 1$ in a dose dependent manner in MDA-MB231cancer cells, while the normal HEK-293 cells were not affected [154]. After an exposure time of $120 \mathrm{~h}$ at the dose of $5 \mu \mathrm{M}$, the decrease of the three markers was already observed.

It is known that the plasma concentrations of these three markers are increased in the plasma of metastatic triple-negative breast cancer (mTNBC) patients [155] and the metastatic triple-negative cancer patients could benefit of the treatment. The IGF-1/ IGF-IR pathway is involved in the migration and invasion of MDA-MB231 cancer cells [156] and VEGF-A is a good marker of angiogenesis in breast cancer patients [157]. Inhibitors of TGF- $\beta 1$ have been proposed to inhibit tumor cell invasion and metastasis, reduce tumor neoangiogenesis, and enhance antitumor immunity. Inhibiting TGF $\beta$ 's immune suppressive effects 
has become of particular interest as demonstrated by the ongoing clinical trials with Galunisertib an inhibitor of the serine/threonine kinase of the TGF- $\beta$ receptor type I [158].

As a consequence of the down-regulation of the biomarkers, an inhibitory effect could be observed, selectively in the cancer cells.

\subsection{Cell effects}

\subsubsection{Uptake and efflux of Re in cells exposed to the Re-diSe drug}

The uptake of Re in the nucleus of different cancer cell lines after having be exposed for $48 \mathrm{~h}$ to the RediSe drug was confirmed by inductively coupled plasma mass spectrometry (ICP-Ms). Efflux from the nucleus was noted after a wash-out period of $48 \mathrm{~h}$ in MCF-7 breast cancer (MCF-7 Mdr and MCF-7 R) resistant cell lines, A549 lung cancer and HeLa uterine cancer cells but not in sensitive MCF-7 cells [159].

\subsubsection{Inhibitory and cytotoxic effects}

Significant inhibitory effects were observed at doses of $50 \mu \mathrm{M}$ for an exposure time of $72 \mathrm{~h}$ in MDAMB231cancer cells, by MTT tests [154]. The effects increased with the duration of time of exposure and were significant at doses of $25 \mu \mathrm{M}$ for an exposure time of $120 \mathrm{~h}$. The same inhibitory effects were observed in hormone dependent breast cancer MCF-7, in prostate PC-3 and colon HT-29 cancer cells, but lung A 549 and uterine HeLa cancer cells were not sensitive. The effects were compared with the diselenide ligand and the superiority of the Re-diSe drug over the free ligand was demonstrated.

A high selective cytotoxicity of Re-diSe was observed in MDA-MB231cancer cells versus normal HEK293 cells, by ethidium bromide test [154], which is more sensitive than the MTT test. Deaths of MDAMB231 cancer cells, established by flow cytometry were statistically significant at the dose of $5 \mu \mathrm{M}$ for an exposure time of $120 \mathrm{~h}$ and increased with the doses. A sharp decrease was observed when increasing the dose from 5 to $25 \mu \mathrm{M}$. In contrast, deaths of normal cells were only significant at doses of $200 \mu \mathrm{M}$ 
[154] and the high selectivity of killing the cancer cells and not normal cells will represent a great advantage in cancer treatment.

\subsection{Pharmacology and toxicology of the rhenium(I)-diselenoether complex}

The tissue distribution of Re and Se has been studied after an oral and daily administration of 10 or 40 $\mathrm{mg} / \mathrm{kg} / 24 \mathrm{~h}, 5$ days a week, for 4 weeks, in mice [159]). Re was absent in control non-treated mice. The main uptake was observed in liver, both for Re and Se, and the concentrations were significantly increased from 10 to $40 \mathrm{mg} / \mathrm{kg}$. The concentrations of Re were also significantly increased with the dose of Re-diSe in blood and kidneys. Se, which is an essential element, was found in all tissues in non-treated mice (controls). The concentrations of Se increased in all tissues of mice treated at the dose of $10 \mathrm{mg} / \mathrm{kg} / 24 \mathrm{~h}$ versus the non-treated mice and in the liver in mice treated at $40 \mathrm{mg} / \mathrm{kg}$ versus those treated at the dose of $10 \mathrm{mg} / \mathrm{kg}$.

The dose of $10 \mathrm{mg} / \mathrm{kg}$ Re-diSe was safe for mice treated daily for 4 weeks either orally in 2 experiments $[21,160]$ or intraperitoneally in another one [161]. This could be the no-adverse toxicity level. This dose was also safe in combination with paclitaxel, but not in a triple combination with cisplatin and a Ga complex (162). Higher doses have not been tested orally. After IP injection, the maximum tolerated dose (MTD) was estimated to be $60 \mathrm{mg} / \mathrm{kg}$. The $50 \%$ letal dose $\left(\mathrm{LD}_{50}\right)$ was noted at the dose of $75 \mathrm{mg} / \mathrm{kg}$. Oral administrations may be less toxic than the parenteral one (IP or IV), and repeated doses less toxic than single one. Moreover, it has been observed that the activity of Re-diSe still increased after the interruption of the treatment [21] and alternating periods with and without treatments could also decrease the toxicity, without affecting the efficacy. The mode of administration by an oral route will have to be preferred to the parenteral route.

\subsection{Antitumor activities in animal experiments of the rhenium(I)-diselenoether complex}


A significant antitumor activity was observed with the Re-diSe drug alone, at the dose of $10 \mathrm{mg} / \mathrm{kg} / 24 \mathrm{for}$ 4 weeks in the MDA-MB231 experimental model, after an oral [21] or IP [161] administration for 4 weeks. A significant reduction of the number of pulmonary metastases was also noted [21]. There was no significant difference between the 10 or $40 \mathrm{mg} / \mathrm{kg}$ doses in terms of reduction of the tumor volumes. The oral daily administration at the dose of $10 \mathrm{mg} / \mathrm{kg}$ for 4 weeks should be the optimal safe dose, significantly reducing both the breast primitive tumor and its metastases.

\subsection{Individual adaptation of the doses of the rhenium(I)-diselenoether complex}

An individual adaptation of doses may nevertheless be proposed, as a function of plasma oxidative markers. Markers of the cancer diseases and of the Se status could also help to manage the treatment and this perspective has been extensively detailed in a review [163]. Se and ROS have a dual role and can either favour of fight the cancer disease. Even with the Re-diSe drug, negative effects may be observed, depending on the experimental conditions. It thus appear useful to monitor the treatment with selected biomarkers. In the case of the metastatic triple negative breath cancer, the decrease of IGF-1, VEGF-A and TGF- $\beta 1$ in the plasma could be markers of the efficacy of the treatment by the Re-diSe anticancer drug.

\section{CONCLUSION}

Non-platinum organometallic compounds did not yet get the approval for the treatment of cancer patients, but Re compounds could be promising clinical candidates. The biophysical properties have been mainly studied with the aim to improve the luminescent effects of $\operatorname{Re}(\mathrm{CO})_{3}$ for diagnostic and compounds PDT, but efforts remain to be done to relate the biological effects with the physical properties. Although, a large variety of rhenium scaffolds have been explored today, many aspect of the Re chemistry remain to be addressed. For example, the influence of the fac/mer configuration on the DNA binding is unknown. Likewise, although only pure enantiomers are considered for the clinical development of small organic 
molecules, asymmetric synthesis or separation of homochiral metal-centered enantiomers are still in infancy. The inhibitory effects on cancer cells have been extensively demonstrated with many Re-drugs, but few compounds have been tested in experimental models with tumor-bearing animals. $\operatorname{Re}(\mathrm{III})$ clusters with a quadrupole bond were very active in synergism with cisplatin in tumor-bearing rats, but not when administered alone. The results might suggested that the observed antitumor effects originated from antioxidant activity. The same anti-oxidant property was observed with a Re-diSe drug which showed selective cytotoxic effects on different human-derived cancer cells. The decreased levels of IGF-1, VEGFA and TGF- $\beta 1$ by these cells might be a consequence of the decreased production of ROS. The binding of Re with guanine has been clearly demonstrated but the exact consequence remains to be defined. Finally, it has been demonstrated that this drug could be orally administered, daily repeated, reducing the tumor growth at a safe dose, with the perspective to personalize and manage the treatment with individual adaptation of doses according to plasma markers (ROS, Se, IGF-1, VEGF-A and TGF- $\beta 1$ ).

If the oxidative system will represent the main target of a Re-diSe drug, in part thanks to the powerful effect of Se on the anti-oxidant system, other targets may be attacked, according to the attached biological molecule. The design of future Re-based compounds will thus take into account the ligand, to increase the lipophilicity, the selective uptake and the pharmacological behaviour, but also the coupled molecule with a specific target on the cancer cell.

\section{CONFLICT OF INTEREST}

Authors declare no conflict of interest.

\section{ACKNOWLEDGEMENT}

Vijay Veena acknowledges the Dr. Bala Manimaran and his research group, Department of Chemistry, Pondicherry University, India for his inspiration in writing this research on the Rhenium based complexes 
and Dr. N. Sakthivel, Department of Biotechnology, Pondicherry University, India for the encouragement in these studies.

\section{REFERENCES}

[1] Collery P, Poirier LA, Manfait M, Etienne JC. In: Metal Ions in Biology and Medicine. John Libbey Eurotext, Paris; 1990: 600.

[2] Anastassopoulou J, Collery P, Etienne JC, Theophanides T. In: Metal Ions in Biology and Medicine. John Libbey Eurotext, Paris; 1992: 453.

[3] Collery P, Poirier L, Littlefield N, Etienne JC. In : Metal Ions in Biology and Medicine: John Libbey Eurotext, Paris; 1994. 585.

[4] Collery P, Corbella J, Domingo JL, Etienne JC, Llobet JM. In :Metal Ions in Biology and Medicine. John Libbey Eurotext, Paris; 1996: 703.

[5] Collery P, Brätter P, Negretti de Brätter V, Khassanova L, Etienne JC. In: Metal Ions in Biology and Medicine. John Libbey Eurotext, Paris; 1998. 775.

[6] Centeno J, Collery P, Vernet G, Finkelman RB, Gibb H, Etienne JC. In: Metal Ions in Biology and Medicine. John Libbey Eurotext, Paris; 2000. 816.

[7] Khassanova LK, Collery P, Maymard I, Khassanova Z, Etienne JC. In: Metal Ions in Biology and Medicine. John Libbey Eurotext, Paris; 2002: 662.

[8] Cser MA, Sziklai Laszlo I, Etienne JC, Maymard I, Centeno J, Khassanova L, et al. In: Metal Ions in Biology and Medicine. John Libbey Eurotext, Paris; 2004: 568 .

[9] Alpoim MC, Morais PV, Santos MA, Cristovao A, Centeno JA, Collery P. In: Metal Ions in Biology and Medicine. John Libbey Eurotext, Paris; 2006: 580.

[10] Collery P, Maymard I, Theophanides T, Khassanova L, Collery T. In: Metal Ions in Biology and Medicine. John Libbey Eurotext, Paris; 2008. 937. 
[11] Pele L, Powell J.J, Kinrad S, Jugdaohsingh R, Collery P, Maymard I, et al. In: Metal Ions in Biology and Medicine. John Libbey Eurotext, Paris; 2011: 307.

[12] Vucina J, Han R. Production and therapeutic use of rhenium-186, 188-the future of radionuclides. Med Pregl 2003; 56: 362-5.

[13] Deutsch E, Brodack JW, Deutsch KF. Radiation synovectomy revisited. Eur J Nucl Med 1993; 20: 1113-27.

[14] Li S, Liu J, Zhang H, Tian M, Wang J, Zheng X.(2001). Rhenium-188 HEDP to treat painful bone metastases. Clin Nucl Med 2001; 26: 919-22.

[15] Wang S-J, Lin W-Y, Chen MN. Rhenium-188 microspheres: a new radiation synovectomy agent. Nucl Med Commun 1998; 19: 427-33.

[16] Leonidova A, Gasser G. Underestimated potential of organometallic rhenium complexes as anticancer agents. ACS Chem Biol 2014; 9: 2180-93.

[17] Gasser G, Ott I, Metzler-Nolte N. Organometallic Anticancer Compounds. J Med Chem 2011, 54, $3-25$.

[18] Konkankit CC, Marker SC, Knopf KM, Wilson JJ. Anticancer activity of complexes of the third row transition metals, rhenium, osmium, and iridium. Dalton Trans 2018; 47: 9934-9974.

[19] Kaur T, Lee WZ, Ravikanth M. Rhenium(I) Tricarbonyl Complexes of meso-Tetraaryl-21,23diheteroporphyrins. Inorg Chem 2016; 55: 5305-11.

[20] Kermagoret A, Morgant G, D’Angelo J, Tomas A, Roussel P, Bastian G, et al. Synthesis, structural characterization and biological activity against several human tumor cell lines of four rhenium(I) diseleno-ethers complexes: $\quad \mathrm{Re}(\mathrm{CO})_{3} \mathrm{Cl}\left(\mathrm{PhSe}\left(\mathrm{CH}_{2}\right)_{2} \mathrm{SePh}\right), \quad \mathrm{Re}(\mathrm{CO})_{3} \mathrm{Cl}\left(\mathrm{PhSe}\left(\mathrm{CH}_{2}\right)_{3} \mathrm{SePh}\right)$, $\mathrm{Re}(\mathrm{CO})_{3} \mathrm{Cl}\left(\mathrm{HO}_{2} \mathrm{C}-\mathrm{CH}_{2} \mathrm{Se}\left(\mathrm{CH}_{2}\right)_{2} \mathrm{SeCH}_{2}-\mathrm{CO}_{2} \mathrm{H}\right)$ and $\mathrm{Re}(\mathrm{CO})_{3} \mathrm{Cl}\left(\mathrm{HO}_{2} \mathrm{CCH}_{2} \mathrm{Se}\left(\mathrm{CH}_{2}\right)_{3} \mathrm{SeCH}_{2} \mathrm{CO}_{2} \mathrm{H}\right)$. Polyhedron 2011; 30: 347-54. 
[21] Collery P, Mohsen A, Kermagoret A, Corre S, Bastian G, Tomas A, et al. Antitumor activity of a rhenium (I)-diselenoether complex in experimental models of human breast cancer. Invest New Drugs 2015; 33: 848-60.

[22] Konkankit CC, Vaughn BA, MacMillan SN, Boros E, Wilson JJ. Combinatorial Synthesis to Identify a Potent, Necrosis-Inducing Rhenium Anticancer Agent. Inorg Chem 2019, 58, 3895-3909.

[23] Muñoz-Osses M, Siegmund D, Gómez A, Godoy F, Fierro A, Llanos L, Aravenad D, Metzler-Nolte N. Influence of the substituent on the phosphine ligand in novel rhenium(I) aldehydes. Synthesis, computational studies and first insights into the antiproliferative activity. Dalton Trans 2018; 47: 13861-9.

[24] Simpson PV, Falasca M, Massi M. Properties and prospects for rhenium(I) tricarbonyl Nheterocyclic carbene complexes. Chem Commun 2018; 54: 12429-38.

[25] Ghosh S, Paul SS, Mitra J, Mukherjea KK. Rhenium(II) nitrosyl complexes: synthesis, characterization, DFT calculations and DNA nuclease activity. J Coord Chem 2014; 67: 1809-34.

[26] Lane SR, Sisay N, Carney B, Dannoon S, Williams S, Engelbrecht HP, et al. Re(V) and Re(III) complexes with sal2phen and triphenylphosphine: rearrangement, oxidation and reduction. Dalton transactions : 2003. 2011; 40: 269-76.

[27] Shtemenko N, Collery P, Shtemenko A. Dichlorotetra- $\mu$-isobutyratodirhenium (III) : enhancement of cisplatin action and RBC-stabilizing properties. Anticancer Res 2007; 27: 2487-92.

[28] Martinez-Lillo J, Mastropietro T. F, Lappano R, Madeo A, Alberto M. E, Russo N, et al. Rhenium(IV) compounds inducing apoptosis in cancer cells. Chem Commun 2011; 47: 5283-5.

[29] Köpf-Maierl P, Klapötke T. Ionic rhenocene derivatives with antitumor activity. Cancer Chemother Pharmacol 1992; 29: 361-6. 
[30] Suntharalingam K, Awuah SG, Bruno PM, Johnstone TC, Wang F, Lin W, Zheng YR, Page JE, Hemann MT, Lippard SJ. Necroptosis-Inducing Rhenium(V) Oxo Complexes. J Am Chem Soc 2015; 137: 2967-74.

[31] Clarke C, Cowley AR, Dilworth JR, Donnelly PS. Pyridylthiocarbazide complexes of rhenium with potential radiopharmaceutical applications. Dalton Trans 2004: 2402-3.

[32] North AJ, Karas JA, Ma MT, Blower PJ, Ackermann U, White JM, Donnelly PS. Rhenium and Technetium-oxo Complexes with Thioamide Derivatives of Pyridylhydrazine Bifunctional Chelators Conjugated to the Tumour Targeting Peptides Octreotate and Cyclic-RGDfK, Inorg Chem 2017; 56: 9725-41.

[33] Martinez-Lillo J, Armentano D, De Munno G, Lloret F, Julve M, Faus J. Synthesis, crystal structure and magnetic properties of an oxalato-bridged Re(IV)Mo(VI) heterobimetallic complex. Dalton Trans 2011; 40: 4818-20.

[34] Sanchis-Perucho A, Rojas-Dotti C, Moliner N, Martínez-Lillo J. Field-induced slow relaxation of magnetisation in an anionic heterotetranuclear $\left[\mathrm{Zn}^{\mathrm{II}} \mathrm{Re}^{\mathrm{IV}}{ }_{3}\right]$ system. Dalton Trans 2019; 48: 370-3.

[35] Pitchumony TS, Banevicius L, Janzen N, Zubieta J, Valliant JF. Isostructural nuclear and luminescent probes derived from stabilized $[2+1]$ rhenium(I)/technetium(I) organometallic complexes. Inorg Chem 2013; 52:13521-8.

[36] Oyarzo J, Acuña A, Klahn H, Arancibia R, Silva CP, Bosque R, López C, Font-Bardía M, Calvis C, Messeguer R. Dalton Trans. Isomeric and hybrid ferrocenyl/cyrhetrenyl aldimines: a new family of multifunctional compounds. Dalton Trans 2018, 47, 1635-1649.

[37] Luengo A, Fernandez-Moreira V, Marzo I, Gimeno MC. Trackable Metallodrugs Combining Luminescent $\operatorname{Re}(\mathrm{I})$ and Bioactive Au(I) Fragments. Inorg Chem 2017; 56: 15159-70. 
[38] Quental L, Raposinho P, Mendes F, Santos I, Navarro-Ranninger C, Alvarez-Valdes A, et al. Combining imaging and anticancer properties with new heterobimetallic $\mathrm{Pt}(\mathrm{ii}) / \mathrm{M}(\mathrm{i})(\mathrm{M}=\operatorname{Re}$, (99m)Tc) complexes. Dalton Trans 2017; 46: 14523-36.

[39] Echeverría C, Becerra A, Nuñez-Villena F, Muñoz-Castro A, Stehberg J, Zheng Z, Arratia-Perez R, Simon F, Ramírez-Tagle R. The paramagnetic and luminescent $\left[\operatorname{Re}_{6} \operatorname{Se}_{8} \mathrm{I}_{6}\right]^{3-}$ cluster. Its potential use as an antitumoral and biomarker agent. New J Chem 2012; 36: 927-932.

[40] Shtemenko, N. I.; Zabitskaya, E. D.; Berzenina, O. V.; Yegorova, D. E.; Shtemenko, A. V. Chem Biodivers 2008, 5: 1660-7.

[41] Yu SH, Patra M, Ferrari S, Ramirez Garcia P, Veldhuis NA, Kaminskas LM, Graham B, Quinn JF, Whittaker MR, Gasser G, Davis TP. J. Linker chemistry dictates the delivery of a phototoxic organometallic rhenium(I) complex to human cervical cancer cells from core crosslinked star polymer nanoparticles. Mater Chem B 2018; 6: 7805-10.

[42] Morimoto T, Ishitani O. Modulation of the Photophysical, Photochemical, and Electrochemical Properties of $\operatorname{Re}(\mathrm{I})$ Diimine Complexes by Interligand Interactions. Acc Chem Res 2017; 50: 267383.

[43] Lo KK-W. Luminescent Rhenium(I) and Iridium(III) Polypyridine Complexes as Biological Probes, Imaging Reagents, and Photocytotoxic Agents. Acc Chem Res 2015; 48: 2985-95.

[44] Lee LC, Leung KK, Lo KK-W. Recent development of luminescent rhenium(i) tricarbonyl polypyridine complexes as cellular imaging reagents, anticancer drugs, and antibacterial agents. Dalton Trans 2017; 46: 16357-80.

[45] Bertrand HC, Clede S, Guillot R, Lambert F, Policar C. Luminescence modulations of rhenium tricarbonyl complexes induced by structural variations. Inorg Chem 2014; 53: 6204-23. 
[46] Yip A M-H, Lo KK-W. Luminescent rhenium(I), ruthenium(II), and iridium(III) polypyridine complexes containing a poly(ethylene glycol) pendant or bioorthogonal reaction group as biological probes and photocytotoxic agents. Coord Chem Rev 2018; 361: 138-63.

[47] Raszeja LJ, Siegmund D, Cordes AL, Güldenhaupt J, Gerwert K, Hahn S, Metzler-Nolte N. Asymmetric rhenium tricarbonyl complexes show superior luminescence properties in live cell imaging. Chem Commun 2017, 53, 905-8.

[48] Palmioli A, Aliprandi A, Septiadi D, Mauro M, Bernardi A, De Cola L, et al. Glyco-functionalized dinuclear rhenium(i) complexes for cell imaging. Org Biomol Chem 2017; 15: 1686-99.

[49] Shestopalov MA, Zubareva KE, Khripko OP, Khripko YI, Solovieva AO, Kuratieva NV, et al. The first water-soluble hexarhenium cluster complexes with a heterocyclic ligand environment: synthesis, luminescence, and biological properties. Inorg Chem 2014; 53: 9006-13.

[50] Kirgan RA, Sullivan BP, Rillema DP. Photochemistry and Photophysics of Coordination Compounds: Rhenium Top. Curr Chem 2007; 281: 45-100.

[51] Hostachy S, Policar C, Delsuc N, Re(I) carbonyl complexes: Multimodal platforms for inorganic chemical biology. Coordin Chem 2017; 351: 172-178.

[52] Leonidova A, Pierroz V, Rubbiani R, Heier J, Ferrari S, Gasser G. Towards cancer cell-specific phototoxic organometallic rhenium(I) complexes. Dalton Trans 2014; 20: 4287-94.

[53] Kastl A, Dieckmann S, Wähler K, Völker T, Kastl L, Merkel AL, et al. Rhenium Complexes with Visible-Light-Induced Anticancer Activity. ChemMedChem 2013; 8(6): 924-7.

[54] Wahler K, Ludewig A, Szabo P, Harms K, Meggers E. Rhenium Complexes with Red-LightInduced Anticancer Activity. Eur J Inorg Chem 2014; 2014: 807-11.

[55] Marker SC, MacMillan SN, Zipfel WR, Li Z, Ford PC, Wilson JJ. Photoactivated in Vitro Anticancer Activity of Rhenium(I) Tricarbonyl Complexes Bearing Water-Soluble Phosphines. Inorg Chem. 2018; 57(3):1311-31. 
[56] Qunlian Huang, Shurong Wang, Jie Zhou, Xiaoyan Zhong and Yilan Huang. Albumin-assisted exfoliated ultrathin rhenium disulfide nanosheets as a tumor targeting and dualstimuli-responsive drug delivery system for a combination chemo-photothermal treatment. RSC Adv 2018; 8: 4624-33.

[57] Luengo A, Fernandez-Moreira V, Marzo I, M. Gimeno C. Bioactive Heterobimetallic Re(I)/Au(I) Complexes Containing Bidentate N-Heterocyclic Carbenes. Organometallics 2018, 37, 3993-4001.

[58] Quental L, Raposinho P, Mendes F, Santos I, Navarro-Ranninger C, Alvarez-Valdes A, et al. Combining imaging and anticancer properties with new heterobimetallic $\mathrm{Pt}(\mathrm{ii}) / \mathrm{M}(\mathrm{i})(\mathrm{M}=\mathrm{Re}$, (99m)Tc) complexes. Dalton Trans 2017; 46: 14523-36.

[59] Solovieva AO, Kirakci K, Ivanov AA, Kubát P, Pozmogova TN, Miroshnichenko SM, Vorontsova EV, Chechushkov AV, Trifonova KE, Fufaeva MS, Kretov EI, Mironov YV, Poveshchenko AF, Lang K, Shestopalov MA. Singlet Oxygen Production and Biological Activity of Hexanuclear Chalcocyanide Rhenium Cluster Complexes $\left[\left\{\operatorname{Re}_{6} \underline{Q}_{8}\right\}(C N)_{6}\right]^{4-}(\mathrm{Q}=\mathrm{S}, \mathrm{Se}, \mathrm{Te})$. Inorg Chem 2017; 56: 13491-9.

[60] Manav N, Kesavan PE, Ishida M, Mori S, Yasutake Y, Fukatsu S, Furuta H, Gupta I. Phosphorescent rhenium-dipyrrinates: efficient photosensitizers for singlet oxygen generation. Dalton Trans 2019; 48: 2467-78.

[61] Kumar U, Roy S, Jha RK, Vidhyapriya P, Sakthivel N, Manimaran B. Selenolato-Bridged Manganese(I)-Based Dinuclear Metallacycles as Potential Anticancer Agents and Photo-CORMs. ACS Omega 2019; 4: 1923-30.

[62] Zobi F, Degonda A, Schaub MC, Bogdanova AY. CO releasing properties and cytoprotective effect of cis-trans-[Re(II)(CO)2Br2L2]n complexes. Inorg Chem 2010; 49(16):7313-22.

[63] Pierri AE, Pallaoro A, Wu G, Ford PC. A Luminescent and Biocompatible PhotoCORM. J Am Chem Soc 2012; 134: 18197-200. 
[64] Chakraborty I, Carrington SJ, Roseman G, Mascharak PK. Synthesis, Structures, and CO Release Capacity of a Family of Water-Soluble PhotoCORMs: Assessment of the Biocompatibility and Their Phototoxicity toward Human Breast Cancer Cells. Inorg Chem 2017; 56: 1534-45.

[65] Chakraborty I, Jimenez J, Sameera WMC, Kato M, Mascharak PK. Luminescent Re(I) Carbonyl Complexes as Trackable PhotoCORMs for CO delivery to Cellular Targets. Inorg Chem 2017; 56: 2863-73.

[66] Carrington SJ, Chakraborty I, Bernard JML, Mascharak PK. A Theranostic Two-Tone Luminescent PhotoCORM Derived from $\operatorname{Re}(\mathrm{I})$ and (2-Pyridyl)-benzothiazole: Trackable CO Delivery to Malignant Cells. Inorg Chem 2016; 55: 7852-8.

[67] Chakraborty I, Carrington SJ, Mascharak PK. Photodelivery of CO by designed PhotoCORMs: correlation between absorption in the visible region and metal-CO bond labilization in carbonyl complexes. ChemMedChem 2014; 9:1266-74.

[68] Kianfar E, Schäfer C, Lornejad-Schäfer MR, Portenkirchner E, Knör G. New photo-CORMs: Deeply-coloured biocompatible rhenium complexes for the controlled release of carbon monoxide. Inorg Chim Acta 2015; 435: 174-7.

[69] Chakraborty I, Jimenez J, Mascharak PK. CO-Induced apoptotic death of colorectal cancer cells by a luminescent photoCORM grafted on biocompatible carboxymethyl chitosan. Chem Commun 2017; 53: 5519-22.

[70] Zobi F, Spingler B, Fox T, Alberto R. Toward novel DNA binding metal complexes: structure and basic kinetic data of $\left[\mathrm{M}(9 \mathrm{MeG})_{2}\left(\mathrm{CH}_{3} \mathrm{OH}\right)(\mathrm{CO})_{3}\right]+(\mathrm{M}=99 \mathrm{Tc}, \mathrm{Re})$. Inorg Chem 2003; 42: 2818-20.

[71] Zobi F, Blacque O, Schmalle HW, Spingler B, Alberto R. Head-to-head (HH) and head-to-tail (HT) conformers of cis-bis guanine ligands bound to the $\left[\operatorname{Re}(\mathrm{CO})_{3}\right]+$ core. Inorg Chem 2004; 43 : 2087 96. 
[72] Zobi F, Spingler B, Alberto R. Guanine and plasmid DNA binding of mono- and trinuclear fac$\left[\operatorname{Re}(\mathrm{CO})_{3}\right]+$ complexes with amino acid ligands. Chembiochem 2005; 6: 1397-405.

[73] Zobi F, Blacque O, Sigel RK, Alberto R. Binding interaction of $\left[\operatorname{Re}\left(\mathrm{H}_{2} \mathrm{O}\right)_{3}(\mathrm{CO})_{3}\right]+$ with the DNA fragment d(CpGpG). Inorg Chem 2007; 46: 10458-60.

[74] Ma D-L, Che C-M, Siu F-M, Yang M, Wong K-Y. DNA Binding and Cytotoxicity of Ruthenium(II) and Rhenium(I) Complexes of 2-Amino-4-phenylamino-6-(2-pyridyl)-1,3,5-triazine. Inorg Chem 2007; 46: 740-9.

[75] Parson C, Smith V, Krauss C, Banerjee HN, Reilly C, Krause JA, et al. The effect of novel rhenium compounds on lymphosarcoma, PC-3 prostate and myeloid leukemia cancer cell lines and an investigation on the DNA binding properties of one of these compounds through electronic spectroscopy. J Bioprocess Biotech 2013; 4: 1-4. doi.org/10.4172/2155-9821.10001.

[76] Parson C, Smith V, Krauss C, Banerjee HN, Reilly C, Krause JA, et al. Anticancer Properties of Novel Rhenium Pentylcarbanato Compounds against MDA-MB-468(HTB-132) Triple Node Negative Human Breast Cancer Cell Lines. Br J Pharm Res 2015; 4(3): 362-7.

[77] Banerjee HN, Vaughan D, Boston A, Thorne G, Payne G, Sampson J, et al. The Effects of Synthesized Rhenium Acetylsalicylate Compounds on Human Astrocytoma Cell Lines. J Cancer Sci Ther 2018; 10(2) doi: 10.4172/1948-5956.1000512.

[78] Medley J, Payne G, Banerjee HN, Giri D, Winstead A, Wachira JM, et al. DNA-binding and cytotoxic efficacy studies of organorhenium pentylcarbonate compounds. Mol Cell Biochem 2015; 398: $21-30$.

[79] Balakrishnan G, Rajendran T, Senthil Murugan K, Sathish Kumar M, Sivasubramanian VK, Ganesan M, et al. Interaction of rhenium(I) complex carrying long alkyl chain with calf thymus DNA: Cytotoxic and cell imaging studies. Inorg Chim Acta 2015; 434: 51-9. 
[80] Wilder PT, Weber DJ, Winstead A, Parnell S, Hinton TV, Stevenson M, et al. Unprecedented anticancer activities of organorhenium sulfonato and carboxylato complexes against hormonedependent MCF-7 and hormone-independent triple-negative MDA-MB-231 breast cancer cells. Mol Cell Biochem 2018; 441:151-63.

[81] Ma D-L, Che C-M, Siu F-M, Yang M, Wong K-Y (2007) DNA Binding and Cytotoxicity of Ruthenium(II) and Rhenium(I) Complexes of 2-Amino-4-phenylamino-6-(2-pyridyl)-1,3,5-triazine. Inorg Chem 2007; 46: 740-9.

[82] Prater ME, Mindiola DJ, Ouyang X, Dunbar KR. A quadruply-bonded dirhenium complex bridged by two N1/N6 adenate ligands. Inorg Chem Commun 1998; 1: 475-7.

[83] Shtemenko NI, Chifotides HT, Domasevitch KV, Golichenko AA, Babiy SA, Li Z, et al. Synthesis, X-ray structure, interactions with DNA, remarkable in vivo tumor growth suppression and nephroprotective activity of cis-tetrachloro-dipivalato dirhenium(III). J Inorg Biochem 2013; 129 : 127-34.

[84] Shtemenko AV, Chifotides HT, Yegorova DE, Shtemenko NI, Dunbar KR. Synthesis and X-ray crystal structure of the dirhenium complex $\operatorname{Re}(i-\mathrm{CHCOO}) \mathrm{Cl}$ and its interactions with the DNA purine nucleobases. J Inorg. Biochem 2015; 153: 114-20.

[85] Ismail MB, Booysen IN, Akerman MP. Oxorhenium(V) complexes with bidentate carbohydrazide Schiff bases: synthesis, characterization and DNA interaction studies. Transition Met Chem 2017, 42: 405-412.

[86] Brinka A, Helliwell. JR New leads for fragment-based design of rhenium/ technetium radiopharmaceutical agents. IUCrJ 2017; 4: 283-90.

[87] Binkley SL, Leeper TC, Rowlett RS, Herrick RS, Ziegler CJ. $\mathrm{Re}(\mathrm{CO})_{3}\left(\mathrm{H}_{2} \mathrm{O}\right)_{3}{ }^{+}$binding to lysozyme: structure and reactivity. Metallomics 2011; 3: 909-16. 
[88] Lecina J, Palacios O, Atrian S, Capdevila M, Suades J. Rhenium and technetium tricarbonyl, $\{\mathrm{M}(\mathrm{CO}) 3\}(+)(\mathrm{M}=\mathrm{Tc}, \mathrm{Re})$, binding to mammalian metallothioneins: new insights into chemical and radiopharmaceutical implications. J Biol Inorg Chem 2015; 20: 465-74.

[89] Lecina J, Carrer A, Álvarez-Larena A, Mazzi U, Melendez-Alafort L, Suades J. New Bioconjugated Rhenium Carbonyls by Transmetalation Reaction with Zinc Derivatives. Organometallics 2012; 31: 5884-93.

[90] Frin KPM, Nascimento VM. Rhenium(I) Polypyridine Complexes as Luminescence-Based Sensors for the BSA Protein. J Braz Chem Soc 2016; 27: 179-85.

[91] Zhang KY, Tso KKS, Louie MW, Liu HW, Lo KKW. A Phosphorescent Rhenium(I) Tricarbonyl Polypyridine Complex Appended with a Fructose Pendant That Exhibits Photocytotoxicity and Enhanced Uptake by Breast Cancer Cells. Organometallics 2013; 32: 5098-102.

[92] Skiba J, Bernas T, Trzybinski D, Wozniak K, Ferraro G, Marasco D, et al. Mitochondria Targeting with Luminescent Rhenium(I) Complexes. Molecules 2017; 22: 809.

[93] Yang J, Zhao JX, Cao Q, Hao L, Zhou D, Gan Z, et al. Simultaneously Inducing and Tracking Cancer Cell Metabolism Repression by Mitochondria-Immobilized Rhenium(I) Complex. ACS Appl Mater Interfaces. 2017; 9: 13900-12.

[94] Kitanovic I, Can S, Alborzinia H, Kitanovic A, Pierroz V, Leonidova A, et al. A deadly organometallic luminescent probe: anticancer activity of a ReI bisquinoline complex. Chem Eur J 2014; 20: 2496-507.

[95] Wang F-X, Liang J-H, Zhang H, Wang Z-H, Wan Q, Tan C-P, Ji L-N, Mao Z-W. Mitochondriaaccumulating rhenium(I) tricarbonyl complexes induce cell death via irreversible oxidative stress and glutathione metabolism disturbance. ACS Appl Mater Interfaces 2019, 11: 13123-33.

[96] Imstepf S, Pierroz V, Rubbiani R, Felber M, Fox T, Gasser G, et al. Organometallic Rhenium Complexes Divert Doxorubicin to the Mitochondria. Angew Chem Int Ed Engl 2016; 55: 2792-5. 
[97] Garcia CV, Parrilha GL, Rodrigues BL, Teixeira SF, de Azevedo RA, Ferreira AK, et al. Tricarbonylrhenium(i) complexes with 2-acetylpyridine-derived hydrazones are cytotoxic to NCIH460 human large cell lung cancer. New J Chem 2016; 40: 7379-87.

[98] Reece SY, Nocera DG. Direct tyrosine oxidation using the MLCT excited states of rhenium polypyridyl complexes. J Am Chem Soc 2005; 127: 9448-58.

[99] Shtemenko N, Pirozhkova-Patalah IV, Shtemenko A. Screening and testing strategy for biological activity of rhenium cluster compounds. In: Metal Ions in Biology and Medicine, John Libbey Eurotext, Paris; 2000; 6: 616-8.

[100] Shtemenko NI, Collery P, Shtemenko AV. Recent advantages in applications of cluster rhenium compounds as antitumor agents. In : Metal Ions in Biology and Medicine, John Libbey Eurotext, Paris; 2008; 10: 441-5.

[101] Leus I, Zabitskaya E, Collery P, Shamelashvili K, Yegorova D, Shtemenko N. Investigation of antioxidant properties of the cluster rhenium compound in the model of tumor growth. In : Metal Ions in Biology and Medicine, John Libbey Eurotext, Paris; 2008; 10: 399-402.

[102] Shtemenko A, Shtemenko N, Oliyvnyk SA, Zelenuk MA. Lyposome forms of rhenium cluster compounds in models of haemolytic anemia. In : Metal Ions in Biology and Medicine, John Libbey Eurotext, Paris; 2002; 7: 558-61.

[103] Pirozhkova-Patalah IV, Shtemenko NI. Influence of cis- $\left[\mathrm{Re}_{2} \mathrm{GABA}_{2} \mathrm{Cl}_{4}\right] \mathrm{Cl}_{2}$ on the antioxidant defense system parameters of normal human blood. Biochemistry (Moscow) 2001; 66: 721-4.

[104] Collery P, Shtemenko N, Shtemenko A, Bourleaud M, Etienne J. C, Maymard I, et al. Supplementation by rhenium compounds instead of iron compounds during the treatment by erythropoietin of anemia in cancer patients. In: Metal Ions in Biology and Medicine, John Libbey Eurotext, Paris; 2004; 8: 534-7. 
[105] Shamelashvili KL, Shtemenko NI, Leus IV, BabIy SO, Shtemenko OV. Changes in oxidative stress intensity in blood of tumor-bearing rats following different modes of administration of rheniumplatinum system. Ukr Biochem J 2016; 8: 29-36.

[106] Skiba J, Kowalczyk A, Stączek P, Bernaś T, Trzybiński D, Woźniak K, Schatzschneider U, Czerwieniec R, Kowalski K. Luminescent fac-[Re(CO) $)_{3}($ phen $\left.)\right]$ carboxylato complexes with nonsteroidal anti-inflammatory drugs: synthesis and mechanistic insights into the in vitro anticancer activity of fac-[Re(CO) $)_{3}($ phen)(aspirin)]. New J Chem 2019; 43: 573-83.

[107] Fricker SP. Cysteine proteases as targets for metal-based drugs. Metallomics 2010; 2: 366-77.

[108] Huisman M, Kodanko JP, Arora K, Herroon M, Alnaed M, Endicott J, Podgorski I, Kodanko JJ. Affinity-Enhanced Luminescent $\mathrm{Re}(\mathrm{I})$ - and $\mathrm{Ru}(\mathrm{II})$-Based Inhibitors of the Cysteine Protease Cathepsin L. Inorg Chem 2018; 57: 7881-91.

[109] Ye R-R, Tan C-P, Lin Y-N, Ji L-N, Mao Z-W. A phosphorescent rhenium(I) histone deacetylase inhibitor: mitochondrial targeting and paraptosis induction. Chem Commun 2015; 51: 8353-6.

[110] New organometallic imines of rhenium(I) as potential ligands of GSK-3ß: synthesis, characterization and biological studies. Muñoz-Osses M, Godoy F, Fierro A, Gómez A, MetzlerNolte N. Dalton Trans 2018; 47: 1233-42.

[111] Mull ES, Sattigeri VJ, Rodriguez AL, Katzenellenbogen JA. Aryl Cyclopentadienyl Tricarbonyl Rhenium Complexes: Novel Ligands for the Estrogen Receptor with Potential Use as Estrogen Radiopharmaceuticals. Bioorg Med Chem 2002; 10: 1381-98.

[112] Wolohan P, Reichert DE. CoMSIA and Docking Study of Rhenium Based Estrogen Receptor Ligand Analogs. Steroids 2007; 72: 247-60.

[113]. Hapuarachchige S, Bryant BK, Arterburn JB. Synthesis of (Pyridin-2-yl)Hydrazone Rhenium(I) Tricarbonyl Complexes that Exhibit pH-Sensitive Fluorescence. Chem Het Compd 2014; 50: 25463. 
[114] Proverbio M, Quartapelle Procopio E, Panigati M, Mercurio S, Pennati R, Ascagni M, Leone R, La Porta C, Sugni M. Luminescent conjugates between dinuclear rhenium complexes and $17 \alpha-$ ethynylestradiol: Synthesis, photophysical characterization, and cell imaging Org Biomol Chem 2019; 17: 509-18.

[115] Viola-Villegas N, Rabideau A. E, Cesnavicious J, Zubieta J, P. DR. Targeting the folate receptor (FR): imaging and cytotoxicity of ReI conjugates in FR-overexpressing cancer cells. ChemMedChem 2008; 3: 1387-94.

[116]. Kaplanis M, Stamatakis G, Papakonstantinou VD, Paravatou-Petsotas M, Demopoulos CA, Mitsopoulou CA. Re(I) tricarbonyl complex of 1,10-phenanthroline-5,6-dione: DNA binding, cytotoxicity, anti-inflammatory and anti-coagulant effects towards platelet activating factor. J Inorg Biochem 2014; 135: 1-9.

[117] Lu G, Hillier SM, Maresca KP, Zimmerman CN, Eckelman WC, Joyal JL, et al. Synthesis and SAR of Novel Re/99mTc-Labeled Benzenesulfonamide Carbonic Anhydrase IX Inhibitors for Molecular Imaging of Tumor Hypoxia. J Med Chem 2013; 56: 510-20.

[118] Burai R, Ramesh C, Nayak TK, Dennis MK, Bryant BK, Prossnitz ER, et al. Synthesis and Characterization of Tricarbonyl-Re/Tc(I) Chelate Probes Targeting the G Protein-Coupled Estrogen Receptor GPER/GPR30. PLoS One 2012; 7(10): e46861.

[119] Leonidova A, Pierroz V, Adams LA, Barlow N, Ferrari S, Graham B, et al. Enhanced Cytotoxicity through Conjugation of a "Clickable" Luminescent $\operatorname{Re}(\mathrm{I})$ Complex to a Cell-Penetrating Lipopeptide. ACS Med Chem Lett 2014; 5: 809-14.

[120] Jiang H, Kasten BB, Liu H, Qi S, Liu Y, Tian M, et al. Novel, Cysteine-Modified Chelation Strategy for the Incorporation of $\left[\mathrm{MI}(\mathrm{CO})_{3}\right]+(\mathrm{M}=\mathrm{Re}, 99 \mathrm{mTc})$ in an $\alpha-\mathrm{MSH}$ Peptide. Bioconjugate Chem 2012; 23(11): 2300-12. 
[121] Mosi R, Baird IR, Cox J, Anastassov V, Cameron B, Skerlj RT, Fricker SP. Rhenium Inhibitors of Cathepsin B (ReO(SYS)X (Where Y= S, py; X = Cl, Br, SPhOMe-p)): Synthesis and Mechanism of Inhibition. J Med Chem 2006; 49: 5262-72.

[122] Giffard D, Fischer-Fodor E, Vlad C, Achimas-Cadariu P, Smith GS. Synthesis and antitumour evaluation of mono- and multinuclear [2+1] tricarbonylrhenium(I) complexes. Eur J Med Chem 2018;157:773-81.

[123] Simpson PV, Casari I, Paternoster S, Skelton BW, Falasca M, Massi M. Defining the Anti-Cancer Activity of Tricarbonyl Rhenium Complexes: Induction of G2/M Cell Cycle Arrest and Blockade of Aurora-A Kinase Phosphorylation. Chem Eur J 2017; 23: 6518-21.

[124] Oliveira BL, Moreira IS, Fernandes PA, Ramos MJ, Santos I, Correia JDG. Theoretical studies on the binding of rhenium(I) complexes to inducible nitric oxide synthase. J Mol Graph Model 2013; 45: $13-25$.

[125] Oliveira BL, Raposinho PD, Mendes F, Figueira F, Santos I, Ferreira A, et al. Re and Tc tricarbonyl complexes: from the suppression of NO biosynthesis in macrophages to in vivo targeting of inducible nitric oxide synthase. Bioconjug Chem 2010; 21: 2168-72.

[126] Bartholoma MD, Vortherms AR, Hillier S, Ploier B, Joyal J, Babich J, et al. Synthesis, cytotoxicity, and insight into the mode of action of $\operatorname{Re}(\mathrm{CO})_{3}$ thymidine complexes. ChemMedChem 2010; 5: 1513-29.

127] Struthers H, Hagenbach A, Abram U, Schibli R. Organometallic $\left[\operatorname{Re}(\mathrm{CO})_{3}\right]+$ and $\left[\operatorname{Re}(\mathrm{CO})_{2}(\mathrm{NO})\right]^{2}+$ labeled substrates for human thymidine kinase 1. Inorg Chem 2009; 48: 5154-63.

[128] Desbouis D, Struthers H, Spiwok V, Kuster T, Schibli R. Synthesis, in vitro, and in silico evaluation of organometallic technetium and rhenium thymidine complexes with retained substrate activity toward human thymidine kinase type 1. J Med Chem 2008; 51: 6689-98. 
[129] König M, Siegmund D, Raszeja LJ, Prokop A, Metzler-Nolte N. Resistance-breaking profiling and gene expression analysis on an organometallic ReI-phenanthridine complex reveal parallel activation of two apoptotic pathways. Med Chem Commun 2018; 9: 173-80.

[130] Ye RR, Tan CP, Chen MH, Hao L, Ji LN, Mao ZW. Mono- and Dinuclear Phosphorescent Rhenium(I) Complexes: Impact of Subcellular Localization on Anticancer Mechanisms. Chemistry Eur J 2016; 22: 7800-9.

[131] Kowalski K, Szczupak Ł, Bernaś T, Czerwieniec R. Luminescent rhenium(I)-chromone bioconjugate: Synthesis, photophysical properties, and confocal luminescence microscopy investigation. J Organomet Chem 2015; 782: 124-30.

[132] Nunes P, Morais GR, Palma E, Silva F, Oliveira MC, Ferreira VF, et al. Isostructural $\operatorname{Re}(\mathrm{I}) /(99 \mathrm{~m}) \mathrm{Tc}(\mathrm{I})$ tricarbonyl complexes for cancer theranostics. Org Biomol Chem 2015; 13: $5182-$ 94.

[133] Clede S, Lambert F, Sandt C, Gueroui Z, Refregiers M, Plamont MA, et al. A rhenium tris-carbonyl derivative as a single core multimodal probe for imaging (SCoMPI) combining infrared and luminescent properties. Chem Commun 2012; 48: 7729-31.

[134] Wedding JL, Harris HH, Bader CA, Plush SE, Mak R, Massi M, et al. Intracellular distribution and stability of a luminescent rhenium(i) tricarbonyl tetrazolato complex using epifluorescence microscopy in conjunction with X-ray fluorescence imaging. Metallomics 2017; 9: 382-90.

[135] North AJ, Hayne DJ, Schieber C, Price K, White AR, Crouch PJ, et al. Toward hypoxia-selective rhenium and technetium tricarbonyl complexes. Inorg Chem 2015; 54: 9594-610.

[136] Choi SJ, Brylev KA, Xu JZ, Mironov YV, Fedorov VE, Sohn YS, et al. Cellular uptake and cytotoxicity of octahedral rhenium cluster complexes. J Inorg Biochem 2008; 102: 1991-6. 
[137] Knopf KM, Murphy BL, MacMillan SN, Baskin JM, Barr MP, Boros E, et al. In Vitro Anticancer Activity and in Vivo Biodistribution of Rhenium(I) Tricarbonyl Aqua Complexes. J Am Chem Soc 2017;139: 14302-14.

[138] Wirth S, Wallek AU, Zernickel A, Feil F, Sztiller-Sikorska M, Lesiak-Mieczkowska K, et al. Tautomerization of 2-nitroso-N-arylanilines by coordination as $\mathrm{N}, \mathrm{N}$-chelate ligands to rhenium(I) complexes and the anticancer activity of newly synthesized oximine rhenium(I) complexes against human melanoma and leukemia cells in vitro. J Inorg Biochem 2010; 104: 774-89.

[139] Huang R, Langille G, Gill RK, Li CM, Mikata Y, Wong MQ, et al. Synthesis, characterization, and biological studies of emissive rhenium-glutamine conjugates. J Biol Inorg Chem 2013; 18: 831-44.

[140] Czaplewska JA, Theil F, Altuntas E, Niksch T, Freesmeyer M, Happ B, et al. Glycoconjugated Rhenium(I) and 99m-Technetium(I) Carbonyl Complexes from Pyridyltriazole Ligands Obtained by “Click Chemistry”. Eur J Inorg Chem 2014; 2014: 6290-7.

[141] Ho J, Lee WY, Koh KJ, Lee PP, Yan YK. Rhenium(I) tricarbonyl complexes of salicylaldehyde semicarbazones: synthesis, crystal structures and cytotoxicity. J Inorg Biochem 2013; 119: 10-20.

[142] Kumar CA, Nagarajaprakash R, Victoria W, Veena V, Sakthivel N, Manimaran B. Synthesis, characterisation and cytotoxicity studies of Manganese(I) and Rhenium(I) based metallacrown ethers. Inorg Chem Commun 2016; 64: 39-44.

[143] Rojas-Mancilla E, Oyarce A, Verdugo V, Zheng Z, Ramirez-Tagle R. The cluster $\left[\operatorname{Re}_{6} \operatorname{Se}_{8} \mathrm{I}_{6}\right]^{3-}$ induces low hemolysis of human erythrocytes in vitro: protective effect of albumin. Intern J Mol Sci 2015; 16: 1728-35.

[144. Uehara T, Koike M, Nakata H, Miyamoto S, Motoishi S, Hashimoto K, et al. In vivo recognition of cyclopentadienyltricarbonylrhenium (CpTR) derivatives. Nucl Med Biol 2003; 30: 327-34. 
[145] Zobi F, Blacque O, Jacobs RA, Schaub MC, Bogdanova AY. 17 e- rhenium dicarbonyl COreleasing molecules on a cobalamin scaffold for biological application. Dalton Trans 2012; 41: 3708.

[146] Shtemenko AV, Collery P, Shtemenko NI, Domasevitch KV, Zabitskaya ED, Golichenko AA. Synthesis, characterization, in vivo antitumor properties of the cluster rhenium compound with GABA ligands and its synergism with cisplatin. Dalton Trans 2009; 26: 5132-6.

[147] Shtemenko N, Collery P, Shtemenko A. Dichlorotetra- $\mu$-isobutyratodirhenium (III): enhancement of cisplatin action and RBC-stabilizing properties. Anticancer Res 2007; 27: 2487-92.

[148] Shtemenko N, Collery P, Shtemenko A. Synergistic effect of cisplatin and cis-rhenium (III) diadamantate on tumor growth. eds Alpoim MC,Vasconcellos Morais P, Santos MA, Cristovao AJ, Centeno JA, Collery P. In: Metal Ions in Biology and Medicine. John Libbey Eurotext, Paris; 2006; 9: $374-81$.

[149] Li Z, Shtemenko NI, Yegorova DY, Babiy SO, Brown AJ, Yang T, et al. Liposomes loaded with a dirhenium compound and cisplatin: preparation, properties and improved in vivo anticancer activity. J Liposome Res 2015; 25: 78-87.

[150] Shtemenko A, Shtemenko N. Rhenium-platinum antitumor systems. Ukr Biochem J 2017; 89: 5-30.

[151] He L, Pan Z-Y, Qin W-W, Li Y, Tan C-P, Mao Z-W. Impairment of the autophagy-related lysosomal degradation pathway by an anticancer rhenium(I) complex. Dalton Trans 2019; 48: 4398404.

[152] Liu C, Zhou L, Wei F, Li L, Zhao S, Gong P, Cai L, Wong K M-C. Versatile Strategy To Generate a Rhodamine Triplet State as Mitochondria-Targeting Visible-Light Photosensitizers for Efficient Photodynamic Therapy. ACS Appl. Mater Interfaces 2019; 11: 8797-806.

[153] Grapperhaus CA, Ouch K, Mashuta MS. Redox-regulated ethylene binding to a rhenium-thiolate complex. J Am Chem Soc 2009; 131: 64-5. 
[154] Collery P, Veena V, Harikrishnan A, Desmaele D. The rhenium(I)-diselenoether anticancer drug targets ROS, TGF- $\beta 1$, VEGF-A, and IGF-1 in an in vitro experimental model of triple-negative breast cancers. Invest New Drugs 2019 https://doi.org/10.1007/s10637-019-00727-1.

[155] Bahhnassy A, Mohanad M, Shaarawy S, Ismail MF, El-Bastawisy A, Ashmawy AM, et al. Transforming growth factor-beta, insulin-like growth factor I/insulin-like growth factor I receptor and vascular endothelial growth factor-A: prognostic and predictive markers in triple-negative and non-triple-negative breast cancer. Mol Med Rep 2015; 12: 851-64.

[156] Bartucci M, Morelli C, Mauro L, Ando S, Surmacz E. Differential insulin-like growth factor I receptor signaling and function in estrogen receptor (ER)-positive MCF-7 and ER-negative MDAMB-231 breast cancer cells. Cancer Res 2001; 61: 6747-54.

[157] Thielemann A, Baszczuk A, Kopczynski Z, Kopczynski P, Grodecka-Gazdecka S. Clinical usefulness of assessing VEGF and soluble receptors sVEGFR-1 and sVEGFR-2 in women with breast cancer. Ann Agric Environ Med 2013; 20: 293-7.

[158] Ikeda M, Morimoto M, Tajimi M, Inoue K, Benhadji KA, Lahn MMF, et al. A phase 1b study of transforming growth factor-beta receptor I inhibitor galunisertib in combination with sorafenib in Japanese patients with unresectable hepatocellular carcinoma. Invest New Drugs 2019; 37(1): 11826.

[159] Collery P, Bastian G, Santoni F, Mohsen A, Wei M, Collery T, et al. Uptake and Efflux of Rhenium in Cells Exposed to Rhenium Diseleno-Ether and Tissue Distribution of Rhenium and Selenium after Rhenium Diseleno-Ether Treatment in Mice. Anticancer Res 2014; 34: 1679-90.

[160] Collery P, Santoni F, Mohsen A, Mignard C, Desmaele D. Negative Impact of Total Body Irradiation on the Antitumor Activity of Rhenium-(I)-diselenoether. Anticancer Res 2016; 36: 58139. 
[161] Collery P, Santoni F, Ciccolini J, Tran TN, Mohsen A, Desmaele D. Dose Effect of Rhenium (I)diselenoether as Anticancer Drug in Resistant Breast Tumor-bearing Mice After Repeated Administrations. Anticancer Res 2016; 36: 6051-7.

[162] Collery P, Mohsen A, Kermagoret A, d'Angelo J, Morgan G, Desmaele D, et al. Combination of Three Metals for the Treatment of Cancer: Gallium, Rhenium and Platinum. 1-Determination of the Optimal Schedule of Treatment. Anticancer Res 2012; 32: 2769-82.

[163] Collery P. Strategies for the development of selenium-based anticancer drugs. J Trace Elem Med Biol 2018; 50: 498-507. 
